\title{
LUCRO Y UNIVERSIDAD
}

A continuación se recogen las cuatro ponencias presentadas en el seminario "Lucro y Universidad" organizado por el Centro de Estudios Públicos el 28 de agosto de 2012, en el orden en que fueron expuestas:

Carlos Peña

"La universidad y el lucro: Cómo impedirlo y por qué"........

Carlos Williamson B.

"Universidad y lucro"

Arturo Fontaine

"Lucro, universidad y filantropía"

Ricardo Paredes

"Universidad y lucro, o el dilema de la cobertura" 


\title{
LA UNIVERSIDAD Y EL LUCRO: CÓMO IMPEDIRLO Y POR QUÉ*
}

\author{
Carlos Peña \\ Universidad Diego Portales
}

La palabra lucro se emplea en dos sentidos: (i) para aludir a los excedentes de una cierta actividad y (ii) para designar al destino de esos excedentes. Así una universidad puede realizar actividades lucrativas (en el primer sentido), pero reinvertir en sus propios fines (en cuyo caso no tiene lucro en el segundo sentido). Respecto del destino de los excedentes de las universidades (lucro en el segundo sentido) deben responderse dos preguntas:

¿Deben permitirse universidades con fines de lucro, es decir, que sus controladores puedan apropiarse de los excedentes? La evidencia disponible indica que es mejor prohibirlas, pues esas instituciones carecen hoy de legitimidad, ayudan a concentrar el poder económico y cultural, pueden perjudicar en el mediano plazo la calidad y no son la única manera de masificar el sistema de educación superior.

¿Cómo asegurar que la regla que prohíbe el lucro no se eluda? Ello puede alcanzarse si: a) se prohíben los contratos con sociedades relacionadas; b) se prohíbe que las sociedades comerciales sean miembros de las corporaciones universitarias; c) se declara nula la cesión a cualquier título del control de la universidad; d) se establecen directorios independientes y personalmente responsables por las decisiones que adoptan; e) se confiere a la Superintendencia el deber de perseguir la responsabilidad de los directores de oficio o a petición de parte. Las reglas anteriores corregirían el principal problema del sistema universitario hoy: su extrema desregulación que lo hace vivir en estado de naturaleza, deslegitimando el importante tránsito que ha experimentado, desde un sistema de élites y excluyente, a uno inclusivo y de masas.

Carlos Peña. Rector de la Universidad Diego Portales, profesor asociado, Facultad de Derecho, Universidad de Chile. Dirección: carlospena@udp.cl.

* Exposición en el seminario "Lucro y Universidad" realizado el 28 de agosto de 2012 en el CEP. Véanse asimismo en esta edición las ponencias presentadas en esa oportunidad por Carlos Williamson, Arturo Fontaine y Ricardo Paredes. (N. del E.) 
$\mathrm{P}$

ocas palabras han sido empleadas, el último tiempo, con mayor profusión y entusiasmo que la palabra lucro. Ella aparece en carteles callejeros, en libros e investigaciones, en consignas encendidas, en eslóganes y en declaraciones de diversa índole. Sin embargo, y a pesar del entusiasmo y la reiteración con que se la emplea, no siempre resulta claro con qué significado se la utiliza.

Así entonces, a la hora de analizar las relaciones que median entre la institución universitaria y el lucro, resulta imprescindible comenzar preguntándonos qué hemos de entender por él.

El lucro, como todo el mundo debería saber, posee dos significados claramente diferenciados entre sí.

Por una parte, se emplea la palabra lucro para aludir a la diferencia que media entre lo que se da y lo que se recibe.

En la Suma Teológica, por ejemplo, Santo Tomás distingue entre el intercambio natural o necesario (que se verificaría cuando alguien da algo que no necesita a cambio de algo que necesita) y el lucrativo (donde alguien da dinero u otro bien por el afán de obtener más dinero). El Doctor Angélico, como suele llamársele, decía que el intercambio de este segundo tipo debía desalentarse porque, dice, "el afán de lucro es infinito" y no tiende por su naturaleza a un fin bueno (Suma Teológica, II-IIae q.77, a 4) ${ }^{1}$. Siglos después, Marx efectúa, en El Capital, la

1 Es propio - observa Santo Tomás - de los comerciantes dedicarse a los cambios de las cosas; y como observa el filósofo en I Pol., tales cambios son de dos especies: una, como natural y necesaria, es decir, por la cual se hace el trueque de cosa por cosa o de cosas por dinero para satisfacer las necesidades de la vida; tal clase de cambio no pertenece propiamente a los comerciantes, sino más bien a los cabezas de familia o a los jefes de la ciudad, que tienen que proveer a su casa o a la ciudad de las cosas necesarias para la vida; la segunda especie de cambio es la de dinero por dinero o cualquier objeto por dinero, no para proveer las necesidades de la vida, sino para obtener algún lucro; y este género de negociación parece pertenecer, propiamente hablando, al que corresponde a los comerciantes. Mas, según el filósofo, la primera especie de cambio es laudable, porque responde a la necesidad natural; mas la segunda es con justicia vituperada, ya que por su misma naturaleza fomenta el afán de lucro, que no conoce límites, sino que tiende al infinito. De ahí que el comercio, considerado en sí mismo, encierre cierta torpeza, porque no tiende por su naturaleza a un fin honesto y necesario.

No obstante, el lucro, que es el fin del comercio, aunque en su esencia no entrañe algún elemento honesto o necesario, tampoco implica por esencia nada vicioso o contrario a la virtud. Por consiguiente, nada impide que ese lucro sea ordenado a un fin necesario o incluso honesto, y entonces la negocia- 
misma distinción sólo que él la efectúa entre lo que llama "circulación simple" (cuando alguien intercambia una mercancía por dinero a fin de obtener otra mercancía, que es lo que hace el trabajador) y "circulación capitalista" (en este último caso se da dinero por una mercancía a fin de obtener más dinero) (El Capital, sección segunda, capítulo iv). A pesar que coincide con el Doctor Angélico a la hora de hacer la distinción, Marx piensa que esta última forma de intercambio es inherente a la acumulación y al progreso que el capitalismo hace posible.

Ahora bien, cuando se sostiene que las universidades no deben perseguir el lucro, y se emplea esta última palabra en el sentido que acabo de identificar, lo que se quiere decir es que la universidad, y el conjunto de sus miembros, deben estar sustraídos de la circulación del capital y de las leyes de la mercancía. Mientras la mayor parte de los seres humanos configura su vida mediante el intercambio, las universidades, se sugiere a veces, deberían estar al margen.

Pero por otra parte, la palabra lucro tiene un sentido estrictamente jurídico.

Cuando se la usa en un sentido jurídico, se la emplea para designar no la diferencia entre lo que se da y lo que se recibe, sino para aludir al destino de los excedentes que son producto de una determinada actividad. En este caso, decir que una cierta institución es sin fines de lucro no significa que ella no participe, por decirlo así, de las leyes de la circulación y de la acumulación capitalista. Lo que se quiere decir es que las ganancias o excedentes que obtenga deben ser reinvertidos o destinados al fin específico para el que la institución que los obtiene fue creada (así lo estableció un Informe del Consejo de Defensa Fiscal: "No procede otorgar personalidad jurídica a las asociaciones que persiguen beneficios económicos indirectos de carácter colectivo") $)^{2}$.

Así entonces, hay dos sentidos en los que puede reclamarse que una universidad no tenga fines de lucro. En uno de ellos se trata de sustraer a la universidad de los avatares del mercado global y a sus miembros, especialmente a los profesores, de los sudores de la competencia. En el otro sentido, en cambio, no se trata de sustraer a la universidad

ción se volverá lícita. Así ocurre cuando un hombre destina el moderado lucro que adquiere mediante el comercio al sustento de la familia o también a socorrer a los necesitados, o cuando alguien se dedica al comercio para servir al interés público, para que no falten a la vida de la patria las cosas necesarias, pues entonces no busca el lucro como un fin, sino remuneración de su trabajo.

${ }^{2} R D J$, Tomo XXXIX, 1942, primera parte, pp. 117-123. 
de los avatares de la competencia y de la acumulación, sino nada más lograr que los excedentes que la universidad obtenga no sean apropiados por individuos u organizaciones ajenos a ella y con fines distintos a la tarea que la legitima.

Si bien en el debate en Chile ambos conceptos suelen confundirse - puesto que a veces parece exigirse que la universidad se sustraiga de la competencia y del mercado y en otras que cumpla la ley actualmente existente - en lo que sigue distinguiré ambos problemas y me referiré a ellos en el mismo orden en que los acabo de enunciar.

Consideremos brevemente el primero de ellos.

El primer problema atinge a las relaciones entre la universidad y la circulación del capital ¿deben las universidades estar sometidas a los rigores de la acumulación del capital y de la competencia para funcionar o, en cambio, deben estar al margen de esas leyes y entregadas, por ejemplo, a alguna forma de mecenazgo estatal o de otra índole? Humboldt, en el discurso de instalación de la Universidad de Berlín, pareció creer que la universidad debía ponerse al margen de la circulación de mercancías: permitan que la universidad se dedique solo a la ciencia, dijo en el discurso inaugural, y todo lo demás vendrá por añadidura ${ }^{3}$. Hoy día las universidades en casi todo el mundo - y en Chile, para qué decir- deben buscar sus propios recursos, o los profesores los suyos, mediante diversas formas de emprendimiento o de competencia. Las universidades, en otras palabras, están cada vez más integradas a lo que Marx llamaba la circulación del capital ¿es necesaria alguna reforma o intervención en este ámbito, en este primer problema que menciono?

${ }^{3}$ El Estado no debe considerar a sus universidades ni como centros de segunda enseñanza ni como escuelas especiales, ni servirse de sus academias como diputaciones técnicas o científicas. En general (pues más adelante diremos qué excepciones concretas deben admitirse respecto a las universidades), no debe exigirles nada que se refiera directamente a él, sino abrigar el íntimo convencimiento de que en la medida en que cumplan con el fin último que a ellas corresponde cumplen también con los fines propios de él, y además, desde un punto de vista mucho más alto, desde un punto de vista que permite una concentración mucho mayor y la movilización de fuerzas y resortes que el Estado no puede poner en movimiento (vid. Fichte et al., La Idea de la Universidad en Alemania, p. 214). 
Pienso que sí, que aunque es necesario tolerar el llamado capitalismo académico - por los beneficios que provee por ejemplo en las relaciones con la empresa - hay también que ponerle límites (límites, no obstáculos) como una forma de resguardar la misión crítica que el trabajo universitario debe poseer en la sociedad. Una universidad puramente funcional, una universidad de emprendedores y no de intelectuales, una universidad que carece de roces con la sociedad en medio de la que funciona, no está, me parece a mí, a la altura de su tarea. Si las universidades nada más cumplieran la función de incrementar el capital humano, entonces no tendría nada de malo que ellas se ajustaran funcionalmente a la circulación capitalista (es decir, que sus actividades estuvieran movidas nada más que por las necesidades de acumulación); pero ocurre que las universidades tienen otras múltiples funciones que van desde incrementar la cohesión social a despertar el espíritu reflexivo de sus miembros y estas últimas funciones pueden ser desalentadas si, para desarrollarlas, se confía sólo en el anhelo de excedentes de sus miembros.

Hay entonces que evitar que la universidad se entregue por entero a lo que Marx llamaba la circulación capitalista.

La universidad moderna nació atada a ideales emancipatorios y a una idea de saber que, no hay duda, parece estar en crisis. Es verdad: ya no es posible pensar a la institución universitaria como el lugar en el que se discierne, y se transmite, lo que es necesario para la libertad o donde se consuma la vida del espíritu. La pérdida de centralidad del estado nacional (que deja, en buena medida, a la universidad sin el sujeto al que originariamente servía); el decaimiento de los metarrelatos (que desprovee de un único sentido al conjunto de sus actividades); y la expansión del mercado (que estimula las conductas orientadas a la búsqueda de rentas), lo impiden. También es verdad que algunos de los valores típicamente universitarios (desinterés institucional, comunismo de resultados, búsqueda de la verdad sin otra consideración) son más débiles que antes o poseen hoy menos fuerza inspiradora. Pero todas esas son buenas razones para tratar de salvar esa dimensión del trabajo universitario y no razones, como a veces se cree, para abandonarla. La dimensión reflexiva del trabajo universitario - esa función que Kant asignaba a lo que él llamaba la facultad inferior- sigue siendo lo más peculiar de la universidad y sin ella las tareas de investigación y de docencia seguirían siendo dignas y útiles; pero no poseerían la particular dignidad que hasta ahora le conferimos. Si bien esa tarea - una tarea crítica en el sentido kantiano - ya no puede ser llevada a cabo en la 
confianza absoluta del saber concebido como totalidad, ese concepto límite - la búsqueda de un saber que se sabe imposible (Derrida, Universidad sin condición, 2002) - sigue estando en el centro del relato que legitima a la vida universitaria.

¿Hay entonces que sustraer del todo a las universidades de las leyes del capital?

No parece posible. Y tampoco conveniente que todas las universidades se aparten de lo que Marx llamaba la circulación del capital, se pongan al margen del lucro en este primer sentido.

Los sistemas de educación superior de masas serían inimaginables si demandáramos de todas las instituciones de educación superior una tarea puramente crítica sustraída a las reglas del capital y del mercado. Instituciones, por decirlo así, puramente humboldtianas no serían capaces de llevar adelante la masificación que las sociedades modernas y democráticas inevitablemente demandan. Lo que se requiere entonces es que el Estado asegure la existencia de un puñado de instituciones que cumplan esas tareas y orienten normativamente el conjunto del sistema.

Como lo muestra el caso de Chile - no vale la pena negar los hechos- la modernización capitalista puede ser extremadamente dinámica a la hora de expandir el acceso a bienes que hasta hace poco estaban nada más que a disposición de una minoría. Nuestro país ha transitado en apenas dos o tres décadas, desde un sistema de educación superior de élites a uno de masas gracias al proceso modernizador que se produjo en la dimensión material de la existencia. A pesar de los problemas que presenta (y que la literatura revela como habituales en estos procesos: bajo capital cultural de los recién incorporados, frustración inicial de sus altas expectativas, menos énfasis en las humanidades y preferencia por las profesiones, pérdida del aura aristocratizante de la universidad), ese proceso ha profundizado la democracia, la secularización de la cultura y la autonomía individual.

El problema no es, pues, ni la masificación de la educación superior, ni la proliferación de instituciones, ni la presencia del capitalismo académico, sino la falta de regulación del proceso. El tránsito entre un sistema de élites a uno de masas se ha producido en medio de un estado de naturaleza carente de reglas. Esa dinámica — donde el proceso modernizador queda entregado a sí mismo- es el que es imprescindible corregir. No para ahogarlo — puesto que, como ya se dijo, él provee importantes bienes que están a la base de la cultura democrática - sino para conducirlo. 
Ahora bien ¿cómo se corrige ese proceso?

Una primera decisión para conducir y gobernar ese proceso es, como se sugiere, la de mantener, al menos para algunas instituciones encargadas de orientar normativamente el sistema, alguna forma de mecenazgo estatal. Ponerlas, en otras palabras, en una medida importante, al margen del lucro en el primer sentido que ya se analizó. Ese mecenazgo les permitiría liberarse, siquiera parcialmente, de los rigores de la competencia y la búsqueda de rentas emprendiendo actividades reflexivas y críticas que carecen de excedentes.

Una segunda decisión - a la que ahora me referiré- debe ser la de contar con reglas claras relativas a los excedentes de las universidades (es decir, con el lucro en el segundo sentido que denantes distinguí). Ello exige, como se verá de inmediato, decidir si han de admitirse las universidades con fines de lucro o no y pensar cómo se asegura que las universidades sin fines de lucro lo sean efectivamente.

Hoy día en el derecho vigente en Chile las reglas proscriben a las universidades con fines de lucro. Esta regla plantea, como se acaba de decir, dos problemas que es necesario examinar separadamente: uno, si acaso esa regla debe mantenerse o si, en cambio, debe permitirse la existencia de universidades con fines de lucro; dos, si el sistema legal cuenta con mecanismos para asegurar que las universidades que formalmente carecen de fines de lucro sean, efectivamente, fieles a esa índole que declaran.

Examinemos brevemente en esta sección el primer problema que este segundo significado del lucro plantea.

¿Debe mantenerse la regla que proscribe a las universidades con fines de lucro o, en cambio, esa regla debe sustituirse por una que permita la existencia de ese tipo de universidades?

Las razones a favor de la admisión de ese tipo de universidades fueron examinadas en el Informe del Consejo Asesor de la Educación Superior ${ }^{4}$. La mayoría de ese Consejo dijo allí que lo decisivo era la política estatal hacia ese tipo de instituciones: si la política estatal, se sugería en ese informe, era restrictiva desde el punto de vista del

${ }^{4}$ Puede consultarse en www.ubiobio.cl/web/descargas/InformeCAPfinal.pdf. 
financiamiento y transparente en la información, podía permitirse su existencia. Una política estatal restrictiva hacia ese tipo de instituciones (tanto en el financiamiento a la oferta como a la demanda) cumplía los mismos objetivos de una regla de prohibición y era menos restrictiva de la libertad según el principio de ponderación ${ }^{5}$. La misma idea se reiteró en el seminario que dio origen a este artículo ${ }^{6}$.

Sin embargo, el debate público ha puesto de manifiesto que esa ponderación es errónea.

El debate público en Chile muestra, en efecto, que es mejor una regla de prohibición, a pesar de lo que la mayor parte de ese Consejo sugirió entonces ${ }^{7}$. Las razones son las que siguen.

a) Desde luego, ese tipo de instituciones podría carecer hoy, en la cultura pública de Chile, de toda legitimidad. La legitimidad — las razones socialmente eficaces para confiar-son esenciales en la tarea educativa. Si esa condición no se cumple - como ocurre hoy con ese tipo de instituciones - el proceso educativo se viene abajo.

b) El debate público ha mostrado también que el argumento que acentúa la calidad de la provisión educativa por sobre la índole del proveedor puede ser una falacia: la calidad de la formación en educación superior no es independiente del ethos de las instituciones. Una institución con fines de lucro orientada en exclusiva a la docencia estandarizada y a la mera funcionalidad (como la experiencia muestra tienden a ser en el largo plazo este tipo de instituciones) carece de algunos aspectos, como la promoción de una cultura reflexiva, que son esperables de la experiencia universitaria. Por supuesto, hay entidades sin fines de lucro que, por otras razones, por ejemplo la adhesión religiosa o ideológica, también perjudican la índole reflexiva de la tarea universitaria.

${ }^{5}$ El principio de ponderación formulado por Alexy, indica que entre dos reglas que persiguen un mismo bien, hay que preferir aquella que permita alcanzarlo al menor coste en otros bienes competitivos.

${ }^{6}$ Fue el punto de vista que expuso Arturo Fontaine quien, a pesar del pobre desempeño que atribuye a ese tipo de universidades (y la opinión desfavorable que por eso le merecen), piensa que no deben prohibirse porque ello restringiría en demasía la libertad.

${ }^{7} \mathrm{El}$ autor de este texto formó parte de esa mayoría que sugirió podía admitirse la existencia de universidades con fines de lucro a condición que hubiera transparencia absoluta y una política estatal restrictiva en el financiamiento. Opinaban de la misma forma el rector de la Universidad Católica, de la Universidad de Santiago, de la Universidad de la Frontera, entre otros. 
c) Ese mismo debate ha puesto de manifiesto que la asociación que suele hacerse entre masificación y tolerancia hacia el lucro no es correcta. La experiencia comparada muestra que la masificación puede alcanzarse sin tolerar la existencia de ese tipo de instituciones. A veces se insinúa a favor de las universidades con fines de lucro, que ellas hacen posible la masificación; otras veces se citan los defectos de la masificación (por ejemplo, el bajo capital cultural de los estudiantes) como un resultado de las instituciones con fines de lucro. Se trata en ambos casos de un error: la masificación es valiosa y es independiente de la índole de las instituciones.

d) En fin, dada la concentración del poder en Chile, permitir que las instituciones de transmisión cultural y formación de las élites estén explícitamente en manos de grupos empresariales, en la más absoluta promiscuidad, les haría daño a los objetivos de difusión del poder que son propios de la democracia.

Así entonces debe concluirse que si, como todos dicen creer, hay que desalentar la existencia de ese tipo de instituciones, es mejor una regla de prohibición que una mera política estatal restrictiva desde el punto de vista del financiamiento.

Ahora bien ¿cómo asegurar que las universidades sean fieles a esa regla?

¿Hay en el derecho vigente en Chile reglas para asegurar que las universidades reinviertan la totalidad de los excedentes que obtienen, es decir, reglas que permitan asegurar la índole sin fines de lucro que declaran?

La respuesta a esa pregunta es que no: no hay reglas que permitan asegurar el carácter sin fines de lucro que las universidades, desde el punto de vista legal, debieran poseer. Las universidades están hoy en medio de un verdadero estado de naturaleza, entregadas a la audacia o la prudencia de quienes las manejan. Por lo mismo es imprescindible imaginar reglas que permitan a todos cerciorarse que las universidades son fieles a la índole que, desde el punto de vista legal, declaran.

¿Cuáles son las formas habituales — cabría preguntarse - en las que esa regla se infringe y cuáles son las reglas que debieran dictarse para evitar que ello ocurra de nuevo? En lo que sigue, enumeraré las di- 
versas formas en que se elude la ley y, al mismo tiempo, señalaré cómo, en mi opinión, ello podría evitarse ${ }^{8}$.

i) Ante todo, esa regla se infringe cuando la universidad realiza contratos y efectúa transferencias con sociedades relacionadas a precios que están por sobre o por debajo de los del mercado.

¿Qué debe entenderse por sociedades relacionadas?

La expresión "sociedades relacionadas" tiene un sentido técnico que la ley define ${ }^{9}$. En conformidad a él, dos sociedades son relaciona-

${ }^{8}$ Sobra decir que la regla que vamos a analizar debe respetarse $-\mathrm{y}$ el sistema legal debe procurar que se respete- con prescindencia de si las universidades con fines de lucro se aceptan o no. El problema de si se admiten o no las universidades con fines de lucro, dice relación con la amplitud de la regla (a qué instituciones se aplica) y no con su obligatoriedad.

${ }^{9}$ Las reglas que definen las operaciones relacionadas, son las que siguen: al cual:

Se encuentra en primer lugar el artículo 146 de la ley 18.046, conforme

[S]on operaciones con partes relacionadas de una sociedad anónima abierta toda negociación, acto, contrato u operación en que deba intervenir la sociedad y, además, alguna de las siguientes personas:

1) Una o más personas relacionadas a la sociedad, conforme al artículo 100 de la ley $\mathrm{N}^{\circ} 18.045$.

2) Un director, gerente, administrador, ejecutivo principal o liquidador de la sociedad, por sí o en representación de personas distintas de la sociedad, o sus respectivos cónyuges o parientes hasta el segundo grado de consanguinidad o afinidad inclusive.

3) Las sociedades o empresas en las que las personas indicadas en el número anterior sean dueños, directamente o a través de otras personas naturales o jurídicas, de un $10 \%$ o más de su capital, o directores, gerentes, administradores, ejecutivos principales.

4) Aquellas que establezcan los estatutos de la sociedad o fundadamente identifique el comité de directores, en su caso, aun cuando se trate de aquellas indicadas en el inciso final del artículo 147.

5) Aquellas en las cuales haya realizado funciones de director, gerente, administrador, ejecutivo principal o liquidador, un director, gerente, administrador, ejecutivo principal o liquidador de la sociedad, dentro de los últimos dieciocho meses.

En segundo lugar se encuentra el artículo 100 de la ley $\mathrm{N}^{\circ} 18.045$. Conforme a él son relacionadas con una sociedad las siguientes personas:

a) Las entidades del grupo empresarial al que pertenece la sociedad;

b) Las personas jurídicas que tengan, respecto de la sociedad, la calidad de matriz, coligante, filial o coligada, en conformidad a las definiciones contenidas en la ley $\mathrm{N}^{\circ} 18.046$;

c) Quienes sean directores, gerentes, administradores, ejecutivos principales o liquidadores de la sociedad, y sus cónyuges o sus parientes hasta el 
das si pertenecen al mismo grupo empresarial; si una de ellas tiene la calidad de matriz, coligante, filial o coligada de la otra ${ }^{10} ; \mathrm{y}$, en general, cuando una de ellas es controlada por la otra mediante la propiedad o algún acuerdo de actuación conjunta. De acuerdo a esa definición - mutatis mutandis - son relacionadas con la universidad las empresas que, junto con ella, están bajo el control del mismo grupo o aquellas

segundo grado de consanguinidad, así como toda entidad controlada, directamente o a través de otras personas, por cualquiera de ellos, y

d) Toda persona que, por sí sola o con otras con que tenga acuerdo de actuación conjunta, pueda designar al menos un miembro de la administración de la sociedad o controle un $10 \%$ o más del capital o del capital con derecho a voto si se tratare de una sociedad por acciones.

La Superintendencia podrá establecer mediante norma de carácter general, que es relacionada a una sociedad toda persona natural o jurídica que por relaciones patrimoniales, de administración, de parentesco, de responsabilidad o de subordinación, haga presumir que:

1. Por sí sola, o con otras con quienes tenga acuerdo de actuación conjunta, tiene poder de voto suficiente para influir en la gestión de la sociedad;

2. Sus negocios con la sociedad originan conflictos de interés;

3. Su gestión es influenciada por la sociedad, si se trata de una persona jurídica, o

4. Si por su cargo o posición está en situación de disponer de información de la sociedad y de sus negocios, que no haya sido divulgada públicamente al mercado, y que sea capaz de influir en la cotización de los valores de la sociedad.

No se considerará relacionada a la sociedad una persona por el solo hecho de participar hasta en un 5\% del capital o 5\% del capital con derecho a voto si se tratare de una sociedad por acciones, o si sólo es empleado no directivo de esa sociedad.

10 Artículo 86. Es sociedad filial de una sociedad anónima, que se denomina matriz, aquella en la que ésta controla directamente o a través de otra persona natural o jurídica más del $50 \%$ de su capital con derecho a voto o del capital, si no se tratare de una sociedad por acciones o pueda elegir o designar o hacer elegir o designar a la mayoría de sus directores o administradores.

La sociedad en comandita será también filial de una anónima, cuando ésta tenga el poder para dirigir u orientar la administración del gestor.

Artículo 87. Es sociedad coligada con una sociedad anónima aquella en la que ésta, que se denomina coligante, sin controlarla, posee directamente o a través de otra persona natural o jurídica el $10 \%$ o más de su capital con derecho a voto o del capital, si no se tratare de una sociedad por acciones, o pueda elegir o designar o hacer elegir o designar por lo menos un miembro del directorio o de la administración de la misma.

La sociedad en comandita será también coligada de una anónima, cuando ésta pueda participar en la designación del gestor o en la orientación de la gestión de la empresa que éste ejerza. 
que controlen la universidad o estén bajo el control de esta última. Así, si una universidad y la empresa $X$ están bajo el mismo control de un tercero, están relacionadas entre sí. Lo mismo ocurre si la empresa $\mathrm{X}$ está bajo el control o propiedad de la universidad o si la universidad está bajo el control de la empresa X. En todos esos casos se trata de sociedades relacionadas.

En conformidad a lo anterior, parece útil distinguir tres situaciones básicas: i) la universidad y la empresa están bajo el control de un tercero o al amparo de un mismo grupo empresarial; ii) la universidad está bajo el control de una empresa; iii) la empresa está bajo el control de la universidad.

De esos tres casos básicos los más riesgosos desde el punto de vista legal son los dos primeros. En ellos la universidad puede ser empleada como fuente de excedentes para un tercero que le es ajeno. El caso iii) en cambio no parece problemático en la medida que la empresa aparece como un instrumento de la universidad y no al revés.

Así, si la universidad $\mathrm{X}$ está bajo el control de un conjunto de personas que son, por su parte, dueños de la inmobiliaria Y, la universidad puede transferir recursos a la inmobiliaria a cambio del empleo de inmuebles. Hasta ahí nada parece reprochable. Sin embargo, y como se trata del mismo controlador, nada impide que la universidad transfiera más recursos por el inmueble que aquellos que hubiera debido dar si lo hiciera por un estricto mecanismo de mercado. Ello podría ocurrir tanto en el caso i) como en el caso ii).

La legislación hasta ahora no lo impide.

Mientras ese tipo de operaciones se encuentran minuciosamente reguladas tratándose de sociedades anónimas, ello no ocurre cuando se realizan entre una sociedad anónima y una universidad que pertenecen al mismo grupo empresarial. En otras palabras, la ley es más rigurosa a la hora de controlar a una sociedad anónima que a la hora de cuidar que las universidades cumplan el fin que les es propio.

En el caso de las sociedades anónimas, este tipo de operaciones no están prohibidas; pero sí se encuentran sometidas a severos requisitos procedimentales descritos en el artículo 147 de la ley respectiva $^{11}$.

${ }^{11}$ Artículo 147. Una sociedad anónima abierta sólo podrá celebrar operaciones con partes relacionadas cuando tengan por objeto contribuir al interés 
social, se ajusten en precio, términos y condiciones a aquellas que prevalezcan en el mercado al tiempo de su aprobación, y cumplan con los requisitos y procedimientos que se señalan a continuación:

1) Los directores, gerentes, administradores, ejecutivos principales o liquidadores que tengan interés o participen en negociaciones conducentes a la realización de una operación con partes relacionadas de la sociedad anónima, deberán informar inmediatamente de ello al directorio o a quien éste designe. Quienes incumplan esta obligación serán solidariamente responsables de los perjuicios que la operación ocasionare a la sociedad y sus accionistas.

2) Antes que la sociedad otorgue su consentimiento a una operación con parte relacionada, ésta deberá ser aprobada por la mayoría absoluta de los miembros del directorio, con exclusión de los directores o liquidadores involucrados, quienes no obstante deberán hacer público su parecer respecto de la operación si son requeridos por el directorio, debiendo dejarse constancia en el acta de su opinión. Asimismo, deberá dejarse constancia de los fundamentos de la decisión y las razones por las cuales se excluyeron a tales directores.

3) Los acuerdos adoptados por el directorio para aprobar una operación con una parte relacionada serán dados a conocer en la próxima junta de accionistas, debiendo hacerse mención de los directores que la aprobaron. De esta materia se hará indicación expresa en la citación a la correspondiente junta de accionistas.

4) En caso que la mayoría absoluta de los miembros del directorio deba abstenerse en la votación destinada a resolver la operación, ésta sólo podrá llevarse a cabo si es aprobada por la unanimidad de los miembros del directorio no involucrados o, en su defecto, si es aprobada en junta extraordinaria de accionistas con el acuerdo de dos tercios de las acciones emitidas con derecho a voto.

5) Si se convocase a junta extraordinaria de accionistas para aprobar la operación, el directorio designará al menos un evaluador independiente para informar a los accionistas respecto de las condiciones de la operación, sus efectos y su potencial impacto para la sociedad. En su informe, los evaluadores independientes deberán también pronunciarse acerca de los puntos que el comité de directores, en su caso, haya solicitado expresamente que sean evaluados. El comité de directores de la sociedad o, si la sociedad no contare con éste, los directores no involucrados, podrán designar un evaluador independiente adicional, en caso que no estuvieren de acuerdo con la selección efectuada por el directorio.

Los informes de los evaluadores independientes serán puestos por el directorio a disposición de los accionistas al día hábil siguiente de recibidos por la sociedad, en las oficinas sociales y en el sitio en Internet de la sociedad, de contar la sociedad con tales medios, por un plazo mínimo de 15 días hábiles contado desde la fecha en que se recibió el último de esos informes, debiendo comunicar la sociedad tal situación a los accionistas mediante hecho esencial.

Los directores deberán pronunciarse respecto de la conveniencia de la operación para el interés social, dentro de los 5 días hábiles siguientes desde la fecha en que se recibió el último de los informes de los evaluadores.

6) Cuando los directores de la sociedad deban pronunciarse respecto de operaciones de este Título, deberán explicitar la relación que tuvieran con la contraparte de la operación o el interés que en ella tengan. Deberán también 
Pues bien. Lo que cabe ahora preguntarse es si acaso esta conocida forma de eludir la ley —o de defraudarla según el enunciado del Digesto: comete fraude a la ley quien respeta la letra pero traiciona el espíritu- puede evitarse extendiendo la regla del artículo 147 de la ley de sociedades anónimas a las universidades o si, en cambio, habrá que establecer alguna regla todavía más rigurosa.

Suele argüirse que es mejor simplemente aplicar la regla del artículo 147, o algo similar, a este tipo de operaciones. Una regla como

hacerse cargo de la conveniencia de la operación para el interés social, de los reparos u objeciones que hubiese expresado el comité de directores, en su caso, así como de las conclusiones de los informes de los evaluadores o peritos. Estas opiniones de los directores deberán ser puestas a disposición de los accionistas al día siguiente de recibidos por la sociedad, en las oficinas sociales así como en el sitio en Internet de las sociedades que cuenten con tales medios, y dicha situación deberá ser informada por la sociedad mediante hecho esencial.

7) Sin perjuicio de las sanciones que correspondan, la infracción a este artículo no afectará la validez de la operación, pero otorgará a la sociedad o a los accionistas el derecho de demandar, de la persona relacionada infractora, el reembolso en beneficio de la sociedad de una suma equivalente a los beneficios que la operación hubiera reportado a la contraparte relacionada, además de la indemnización de los daños correspondientes. En este caso, corresponderá a la parte demandada probar que la operación se ajustó a lo señalado en este artículo.

No obstante lo dispuesto en los números anteriores, las siguientes operaciones con partes relacionadas podrán ejecutarse sin los requisitos y procedimientos establecidos en los números anteriores, previa autorización del directorio:

a) Aquellas operaciones que no sean de monto relevante. Para estos efectos, se entiende que es de monto relevante todo acto o contrato que supere el $1 \%$ del patrimonio social, siempre que dicho acto o contrato exceda el equivalente a 2.000 unidades de fomento y, en todo caso, cuando sea superior a 20.000 unidades de fomento. Se presume que constituyen una sola operación todas aquellas que se perfeccionen en un período de 12 meses consecutivos por medio de uno o más actos similares o complementarios, en los que exista identidad de partes, incluidas las personas relacionadas, u objeto.

b) Aquellas operaciones que, conforme a políticas generales de habitualidad, determinadas por el directorio de la sociedad, sean ordinarias en consideración al giro social. En este último caso, el acuerdo que establezca dichas políticas o su modificación será informado como hecho esencial puesto a disposición de los accionistas en las oficinas sociales y en el sitio en Internet de las sociedades que cuenten con tales medios, sin perjuicio de informar las operaciones como hecho esencial cuando corresponda.

c) Aquellas operaciones entre personas jurídicas en las cuales la sociedad posea, directa o indirectamente, al menos un $95 \%$ de la propiedad de la contraparte. 
esa, se dice, no lesionaría la economía política del sistema y evitaría las transferencias forzosas de las inmobiliarias a las universidades.

Mi opinión, sin embargo, es que resulta mejor prohibir del todo los contratos entre una universidad y alguna sociedad relacionada, es decir, una sociedad que comparte el mismo control con la universidad. Así, entonces, si una universidad se relaciona con una inmobiliaria a la que arrienda los inmuebles que ocupa, y ambas se encuentran bajo el mismo control, la condición para que esos contratos pudieran mantenerse, si una regla de prohibición se aprobara, es que los controladores elijan de qué lado del mesón preferirían estar.

Una regla como esa, me parece a mí, evita la transferencia forzosa de bienes (la transferencia forzosa tiene el problema de que es muy difícil fijar el precio ${ }^{12}$ y su constitucionalidad es dudosa). La regla de prohibición obligaría simplemente a los controladores a escoger entre mantener el control de la universidad desprendiéndose de la sociedad de que se trata o, en cambio, optar por el control de la sociedad desprendiéndose del control de la universidad. Al revés de lo que pudiera creerse, cuando se prohíben este tipo de contratos no se desalientan los intercambios, sino los conflictos de interés con los que se realizan.

En fin, todavía existe una ventaja adicional. Una regla como la que sugiero - que no lesiona, como acabo de decir, la economía política del sistema - todavía permite separar a las instituciones de transmisión cultural, como son las universidades, de los negocios puramente mercantiles. En Chile se han hecho esfuerzos por separar a la política de los negocios ¿por qué no hacer esfuerzos similares para separar los negocios de la tarea de la transmisión de la cultura?

ii) Pero la celebración de contratos con sociedades relacionadas no es la única forma en que se infringe la regla que estamos analizando. Todavía se la infringe, y es frecuente que así ocurra, cuando los miembros de la universidad transfieren a título oneroso a un tercero el control que poseen sobre la institución.

¿Cómo podría ocurrir lo que acabo recién de señalar?, ¿cómo es posible que siendo las universidades entidades no lucrativas, respecto de las cuales no existe propiedad alguna, se transfiera sin embargo su control a cambio, todavía, de un precio?

${ }^{12}$ Uno de los contratantes puede estar en condiciones de extraer todo el excedente al otro. 
Para comprender lo anterior, es imprescindible repasar, siquiera brevemente, la manera en que una universidad puede organizarse.

Las universidades se organizan o como fundaciones o como corporaciones. El elemento que constituye esencialmente a las primeras, a las fundaciones, es el patrimonio que el fundador destina al fin que quiere servir. El elemento que constituye, por su parte, de manera esencial a las corporaciones, es el conjunto de los socios que se coalicionan para perseguir un fin de interés público. Ahora bien, la ley no establece qué carácter han de poseer los socios: para que una corporación exista basta que los haya.

Y ahí entonces surge el problema.

Porque ocurre que algunas universidades se organizan como corporaciones sin fines de lucro; pero sus socios son personas jurídicas lucrativas. Así, la universidad X es incuestionablemente sin fines de lucro, puesto que es una corporación; pero los miembros que integran a esta última, aquellos cuya voluntad la gobierna, pueden ser, en el derecho vigente en Chile, personas jurídicas con fines de lucro, por ejemplo, sociedades comerciales o civiles. Así entonces el control de la universidad puede ser objeto de una transferencia onerosa. Ello ocurre si se vende la participación en la sociedad que, por integrar la corporación, contribuye a forjar su voluntad. Se explica así entonces el misterio, tantas veces repetido entre nosotros, que una universidad mantenga incólume su carácter sin fines de lucro; pero sea, al mismo tiempo, y a la vista y paciencia de todos, objeto de transacciones comerciales.

Seguramente todos ustedes recuerdan el Caso Chispas. En este caso un grupo de managers transformó las indemnizaciones a que tenían derecho en acciones de la compañía que administraban. Sus acciones tenían, sin embargo, una particularidad: los derechos económicos sobre el capital estaban por debajo de los derechos políticos que los tenedores de esas acciones tenían a la hora de elegir al directorio. Los tenedores de esas acciones decidieron venderlas a un precio superior atendido el hecho que no vendían sólo el capital, sino el control político sobre él. La operación fue considerada un escándalo y quienes participaron de ella sufrieron altísimas penas pecuniarias. ¿Cuál era el pecado de esos managers? Su pecado fue haber vendido a precio preferente el control o los derechos políticos de una sociedad anónima en perjuicio de los minoritarios.

Pues bien. Si los managers de que se trata hubieran vendido el control de una universidad — es decir, si hubieran vendido las acciones 
de una compañía que integra la asamblea de socios de una corporación universitaria y hubieran cobrado un sobreprecio de control- nadie podría haberles dicho nada. La operación, bajo el derecho vigente, habría sido perfectamente lícita.

¿Es correcto - ya no bajo las reglas del derecho vigente, sino ahora desde el punto de vista de un buen diseño universitario- que pueda transferirse el control de las universidades a título oneroso?

Mi opinión es que no, creo que eso no es correcto.

Las universidades deben ser entidades autónomas, provistas de una voluntad propia, y no organizaciones dependientes de un poder extraño o ajeno a sí misma. Menos organizaciones cuya estructura de poder dependa de las leyes bajo las cuales circulan las mercancías. ¿Cómo va a ser sensato que una universidad no sepa cuál es la voluntad que la gobierna porque esa voluntad puede cambiar, de un día para otro, al compás de la oferta y la demanda?

Para evitar lo anterior, es necesario establecer que los miembros de la corporación universitaria deban ser, en cualquier caso, personas naturales. De esa manera se evita que los miembros de la corporación sean sociedades comerciales y que (como ocurre hoy) la venta de las acciones o de la cuota de participación en estas últimas equivalga a la venta del control de la universidad. Igualmente deben preverse reglas que eviten la cesión a cualquier título del control o gobierno de la universidad $^{13}$.

iii) La consideración anterior - relativa a dónde radica el poder que gobierna a la universidad, si en el intercambio o en la deliberación - obliga a considerar, siquiera brevemente, el tema del gobierno de las universidades. Creo, como insistiré de inmediato, que el gobierno de las universidades se relaciona directamente con el tema del lucro que venimos considerando (una revisión de las relaciones entre formas de gobierno y respeto de las reglas, en David Farber, "Restoring Trust after Fraud: Does Corporate Governance Matter?”, pp. 539-561). En el

${ }^{13}$ Las reglas debieran ser similares a las que siguen:

- Se prohíbe cualquier acto o contrato por el que el directorio ceda o transfiera, total o parcialmente, y a cualquier título, sus funciones esenciales o se comprometa a ejercerlas bajo una determinada modalidad.

- Hay objeto ilícito en todo acto o contrato por el que se transfiera, a título gratuito u oneroso, una posición de control en una corporación o fundación universitaria, aunque ello se haga modificando los estatutos. 
mismo punto - la relación entre gobierno universitario y reglas - en Secretary of Education and Training, Review of University Governance (Australia, 2002).

Como todo el mundo sabe (Coase, si no recuerdo mal, fue uno de los primeros que llamó la atención acerca de esto en "The Nature of the Firm", pp. 386-405) las empresas que funcionan en el mercado se organizan, paradójicamente, en términos de no mercado, como un conjunto de recursos gobernados por un poder central. Todo esto plantea el problema, suficientemente conocido, del gobierno de las organizaciones: quién manda a quién y cómo se controla a los que mandan.

En el caso de las sociedades anónimas abiertas, este problema se resuelve más o menos de la siguiente forma: el poder final se radica en los propietarios reunidos en la junta de accionistas quienes, por su parte, y en proporción a la propiedad, designan a un directorio el que, a su turno, designa a los administradores directos. La tarea del directorio, sin embargo, no es cuidar los intereses de quienes los designaron sino los intereses de la sociedad o de la empresa en su conjunto. El principal es la sociedad (cuya voluntad se actualiza en la junta de accionistas) y el agente es el directorio (cuyo papel es fiduciario y consiste en cuidar que la administración no traicione los intereses del principal). Ahora bien, a fin de asegurar que los directores cumplan las reglas de la sociedad y cuiden los intereses sociales (es decir, los intereses de todos y no sólo de los minoritarios) la ley dispone que los directores son personalmente responsables por los acuerdos a los que concurren: responden, pues, con su patrimonio personal si abandonan el estándar de cuidado que la ley impone para los intereses sociales.

En suma, el problema del gobierno de las sociedades anónimas se resuelve de manera correcta en la medida que la relación de agencia es clara (se sabe quién es el principal y quién el agente) y la responsabilidad se encuentra bien definida (recae, como acabamos de ver, personalmente sobre los directores).

¿Qué ocurre, sin embargo, en las universidades, especialmente en las universidades privadas creadas luego de 1981 ?

Lo que ocurre es que en esas universidades ni la relación de agencia es clara, ni la responsabilidad se encuentra bien definida.

Desde el punto de vista legal, las corporaciones y fundaciones se constituyen con fines de interés público o social, en cualquier caso, con 
fines de servicio distintos de la mera suma de los intereses de quienes las constituyen. Ésta es una conclusión que en la literatura ya no se discute. Por lo mismo, las corporaciones y fundaciones - que es, como sabemos, la forma en que se constituyen las universidades - deben servir los intereses y los propósitos para los que fueron creadas y la labor de todos sus órganos es asegurar que ello ocurra. La relación de agencia en las universidades, en consecuencia, debe establecerse entre los propósitos de la universidad y el directorio.

Desgraciadamente ello no suele ocurrir en la práctica. En la práctica, que es donde importa, los controladores de las universidades suelen actuar como propietarios de ellas y el directorio, que a veces coincide con esa relación de propiedad, actúa como su agente. En otras palabras, en las universidades privadas se arriesga el peligro de reproducir la relación de agencia de las sociedades, cuando se trata de realidades que, sin embargo, son muy distintas. La ley, por su parte, nada dice respecto de los deberes del directorio de una universidad. Esos deberes, hemos visto, no pueden ser otros que los de cautelar el interés que la corporación o la fundación universitaria declaró servir al momento de constituirse y no los intereses de los controladores. Sin embargo, a diferencia de lo que ocurre en las sociedades anónimas, el derecho vigente en Chile guarda silencio acerca de los deberes de los directores de universidades (por supuesto, alguna regla puede derivarse del mandato; pero no existe, como digo, regla explícita alguna en esta materia lo que crea incertidumbre y favorece la anomia).

A lo anterior se suma que tampoco existe una regla de responsabilidad personal de los directores de universidades por los acuerdos a que concurran y que acaben perjudicando el interés de la corporación o de la fundación.

Este problema es especialmente severo.

Ninguna regla tendrá éxito en estas materias si no se exige que exista un directorio explícita y personalmente responsable de hacerla cumplir. Como todos saben, es más eficiente socialmente poner el riesgo de cargo de aquellos que pueden evitarlo al menor costo. Siguiendo ese principio, parece obvio que es necesario, y eficiente, poner el riesgo de incumplimiento de la ley por parte de las universidades de cargo de los directores, instituyendo a la Superintendencia con la titularidad de la 
acción para ejercerla, de oficio o a petición de parte. No es difícil, desde el punto de vista técnico, prever esas reglas ${ }^{14}$.

Así entonces, para hacer cumplir la regla que prescribe que las universidades han de ser sin fines de lucro, es necesario prohibir los contratos con sociedades relacionadas, impedir que las corporaciones se organicen con miembros que equivalgan a sociedades comerciales o civiles y disponer la existencia de directorios independientes y personalmente responsables cuyo deber sea servir los fines para los que la universidad fue autorizada.

¿Acabarán las prácticas que hemos relatado una vez qué reglas como las que menciono se adopten?

Es probable que no. Es más fácil, dijo Zizek, imaginar el fin del mundo que la muerte del capitalismo y de su casi infinita plasticidad ${ }^{15}$;

${ }^{14}$ Para ello habría que establecer reglas como las que siguen.

- Las universidades debieran administrarse por un directorio o consejo directivo designado en la forma prevista por los estatutos de la respectiva corporación o fundación. La designación debe ser por el plazo que señalen los estatutos, el que no debiera ser inferior a tres años.

- Una vez nombrados, los directores son independientes de todo interés particular y no podrán ser removidos de su cargo sino por mayoría del directorio y por causa grave señalada previamente en los estatutos.

- Será deber esencial de los directores velar por el fiel cumplimiento de los estatutos de la Corporación o Fundación y el íntegro respeto de la ley. En el ejercicio de sus funciones, los directores universitarios no representan el interés de quien los designó ni cualquier otro interés particular, sino que actúan en interés del conjunto de la Corporación o Fundación.

- Los directores deberán emplear en el ejercicio de sus funciones el cuidado y diligencia que los hombres emplean ordinariamente en sus propios negocios y responderán solidariamente, y con su patrimonio, de los perjuicios causados a la Corporación o Fundación. Corresponderá a la Superintendencia de oficio o a petición de parte, perseguir judicialmente esa responsabilidad.

- Si la universidad recibe financiamiento público, al menos uno de sus directores deberá ser designado por el Estado. La tarea de este director será la de tutelar el interés público comprometido en la administración de la universidad.

- Es nula toda estipulación del estatuto que tienda a liberar o a limitar la responsabilidad de los directores a que se refiere el inciso anterior.

- Es función esencial del directorio de la Corporación o Fundación universitaria la de supervigilar la administración financiera y patrimonial de la entidad cuidando que se ciña estrictamente a la ley.

Las universidades actualmente existentes tendrán un plazo de seis meses para adecuar sus órganos de gobierno a lo previsto en las reglas anteriores.

15 http://philosomatic.tumblr.com/post/11602788564/slavoj-zizekspeaks-to-occupy-wall-street. 
pero así y todo no cabe duda que con reglas como esas el sistema funcionará mejor y estará, más que hoy día, a la altura de sus compromisos públicos.

\section{REFERENCIAS BIBLIOGRÁFICAS}

Consejo de Defensa Fiscal. "Informe". En RDJ, tomo XXXIX. Santiago de Chile.

Derrida, J. Universidad sin Condición. Madrid: Trotta, 2002.

Farber, David. "Restoring Trust after Fraud: Does Corporate Governance Matter?" The Accounting Review, Vol. 80, № 2.

Fichte, J.G., F. Schleiermacher, W. von Humboldt, F. Nietzsche, De Lagarde, M. Weber, M. Scheler, K. Jaspers. La Idea de la Universidad en Alemania. Buenos Aires: Sudamericana, 1959.

Secretary of Education and Training. Review of University Governance. Australia, 2002.

Zizek, Slavoj. En http.//philosomatic.tumbir.com/post/11602788654/slavojzizek-speaks-to-occupy-wall-steet. 


\title{
UNIVERSIDAD Y LUCRO*
}

\author{
Carlos Williamson B. \\ Universidad Católica de Chile
}

La educación universitaria se ha de proteger del oportunismo de "concesionarios" que defrauden la fe pública. Pero el modelo sin fines de lucro no debe verse como la única opción para organizar la educación universitaria. En efecto, es discutible que no sea posible configurar un sistema que permita aprovechar la fuerza emprendedora de particulares, que con visión empresarial provean educación de calidad a cambio de una renta que compense los riesgos de la inversión.

La calidad no es un atributo asociado a aquellas universidades que se identifican como sin fines de lucro, sean éstas de carácter público o privado. Un vasto número de universidades privadas con fines de lucro muestran indicadores respetables, o si se quiere, no sustantivamente distintos del resto. Conceptualmente, el lucro puede coexistir con la calidad del proyecto educativo en la medida en que la calidad garantiza la sustentabilidad económica del proyecto en el largo plazo.

En Chile, la ley vigente prohíbe el lucro, por lo que su cumplimiento no es una opción sino una condición para participar lealmente en el sistema. El nudo gordiano del problema del lucro está en las sociedades comerciales que tienen la propiedad de los inmuebles. Se ha planteado diseñar una transición de venta normada a las fundaciones o corporaciones universitarias de origen. Para evitar que se defraude la normativa que prohíbe el lucro en universidades ya instaladas, no basta con incorporar directores independientes como garantes para visar esas transacciones, sino que debiese ser exigible, además, la contratación de entidades especializadas autónomas para fijar adecuadamente estos precios de transferencia.

Carlos Williamson B. Profesor (y ex prorrector) de la Universidad Católica de Chile. Actualmente es director nacional del Servicio Civil. Dirección electrónica: cwilliam@uc.cl.

Agradezco la valiosa colaboración de Fernanda Vicuña en el manejo de las estadísticas, elaboración de cuadros y análisis de información.

* Exposición en el seminario "Lucro y Universidad" realizado el 28 de agosto de 2012 en el CEP. Véanse también en esta edición las ponencias presentadas en esa oportunidad por Carlos Peña, Arturo Fontaine y Ricardo Paredes. (N. de. E.) 


\section{Introducción}

$\mathrm{L}_{\mathrm{a}}$

discusión sobre el lucro en la educación se ha instalado como uno de los temas de mayor controversia a la hora de analizar el resultado de las políticas educacionales en nuestro país, generando mucho debate sobre sus efectos en el desarrollo de este sector en las últimas décadas. Lo que hasta hace pocos años no pasaba de ser apenas un rasgo distintivo del sistema chileno; a saber, el lucro es admisible en la educación escolar y en la superior de carácter técnico y profesional, pero no está permitido en la universitaria, y la sola mención de la palabra lucro pasaba prácticamente desapercibida, hoy aparece como un fenómeno que no deja a nadie indiferente.

Este artículo pretende entrar a esta polémica aportando algunos antecedentes que sirven para contextualizar la discusión sobre el lucro en el ámbito universitario. Interesa el tema porque es sabido que en Chile, si bien la legislación solo admite la creación de universidades sin fines de lucro, en la práctica se puede lucrar en la medida en que la legislación no prohíbe la creación de sociedades comerciales relacionadas con los controladores de la universidad y por esa vía es posible transferir las utilidades del "negocio" universitario fuera de su propio ámbito.

Hay varias interrogantes en relación al lucro y me centraré en dos de ellas. Intentar una respuesta, desde luego, a la pregunta que puede parecer retórica en un país que prohíbe el lucro, pero parece pertinente a la luz de la realidad actual y, por lo demás, ha sido una pregunta tantas veces hecha sin una respuesta clara y precisa. Ella apunta a dilucidar los efectos del lucro en el desarrollo de un sistema universitario capaz de exhibir una amplia cobertura y de ofrecer una educación de calidad. $\mathrm{Si}$ el lucro supone extraer recursos que, de otro modo, reinvertidos en la propia universidad potenciarían su proyecto educativo, entonces su prohibición parecería socialmente deseable. Sin embargo, para que ello ocurra primero tiene que haber un emprendimiento privado que esté dispuesto a poner capital, renunciando a obtener una rentabilidad atractiva sobre los recursos invertidos que vaya en beneficio propio. En la práctica, esto sucede con aquellas universidades privadas que se organizan sin la creación paralela de sociedades comerciales, o bien, cuando las sociedades comerciales que se crean tienen un objetivo y estructura jurídica donde los excedentes se reinvierten en ella misma. Pero eso tiene límites. Porque es cierto que al prohibir el lucro otros emprendedores 
privados que sí persiguen un beneficio económico podrían restarse a participar en esta industria y la cobertura educacional sería menor, excepto que el Estado amplíe su participación y destine recursos adicionales al ámbito universitario, los mismos que podrían tener mejores usos alternativos como gasto social en áreas más prioritarias. En el fondo, la apertura del Estado a la inversión privada en la educación universitaria, concesionando el derecho a ofrecer grados académicos y títulos profesionales a entidades privadas con fines de lucro no es distinto a la concesión de otros bienes públicos. Aunque es cierto que la educación universitaria, con su carácter de bien público sujeto a externalidades positivas, debe protegerse con mucho mayor celo frente al riesgo del oportunismo de "concesionarios" que defrauden la fe pública, es discutible el que no sea posible configurar un sistema que permita aprovechar la fuerza emprendedora de particulares, que con visión empresarial provean educación de calidad a cambio de una renta que compense los riesgos de la inversión.

La segunda pregunta es más incisiva y entra de lleno a la polémica. Aun si la prohibición del lucro fuese cuestionable, ¿cómo hacer cumplir la ley que excluye esa opción? Más aún, ¿fue correcto que la Ley General de Educación del año 1981, por omisión, permitiera las sociedades relacionadas? Actualmente, el Gobierno ha decidido legislar mediante un proyecto de ley que crea una Superintendencia de Educación Superior que, entre otras materias, visará que se cumpla la ley vigente, manteniendo la opción de mantener sociedades relacionadas, pero sancionando el lucro. ¿Es ese el mejor modo para hacer cumplir la letra y el espíritu de la legislación vigente?, ¿hay mejores opciones?

\section{El modelo sin fines de lucro en la educación universitaria}

La razón de que impere un modelo de organización societaria sin fines de lucro respecto a las universidades, aun estando permitido el lucro, es reflejo en buena medida del fenómeno que en economía se conoce como asimetrías de información. En concreto, se dice que en los mercados donde hay ausencia de información por parte del comprador respecto a las características del bien que adquiere del oferente, el comprador pasa a ser muy vulnerable frente a comportamientos oportunistas del vendedor. Dicho de otro modo, dada esta asimetría de información, es difícil suscribir contratos que garanticen al detalle y de un modo cer- 
tero que la calidad del bien que se compra será efectivamente la esperada. En dichos mercados la creación de lazos de confianza reemplaza a los contratos tradicionales, porque es la confianza lo que permite que el demandante acepte, un poco a ciegas, las condiciones del oferente. En consecuencia, la mejor garantía para construir esa confianza y que sea creíble es la adopción de un modelo de administración sin fines de lucro, porque eso fortalece la percepción del consumidor de que la empresa no tendrá otro objetivo que responder a la promesa de un producto con los atributos esperados.

Esta caracterización tiene enorme importancia al momento de analizar cómo se organizan las universidades de un país. En las universidades se cumple el supuesto de información asimétrica: los estudiantes, o sea quienes demandan educación, cuentan con información imperfecta o difícil de asimilar para una elección que no tenga un grado importante de incertidumbre. En ese contexto, el no lucro como modelo de gestión universitaria se presenta como una señal para neutralizar la desconfianza del alumno o de su sostenedor. Aquí el concepto de lucro no niega la posibilidad de que las universidades puedan eventualmente generar excedentes. Por el contrario, si de una buena gestión se obtienen excedentes económicos, en buena hora. No, el énfasis en el "no lucro" está puesto más bien en el sentido de que en tales instituciones no hay que rendir cuentas a terceros, digamos a los dueños del capital, quienes exigirían una rentabilidad por la inversión como ocurre en el mundo empresarial corporativo y por esa vía extraer rentas. Por decirlo de otro modo, la universidad responde a su fundador, ella misma, y declara por ese acto su voluntad de concentrar sus esfuerzos en formar estudiantes y generar nuevo conocimiento renunciando a retirar los excedentes de la operación.

Con todo, el modelo sin fines de lucro no necesariamente debe verse como la única opción para organizar la educación universitaria sin las amenazas de operadores que defraudan la confianza y la fe pública. Conceptualmente, el lucro puede coexistir con la calidad del proyecto educativo en la medida en que la calidad garantiza la sustentabilidad económica del proyecto en el largo plazo. Es decir, hay incentivos a evitar el engaño porque en algún momento el mercado castiga a quien defrauda la fe pública. En otras palabras la inversión en reputación se rentabiliza y actúa como un factor disuasivo que frena comportamientos 
oportunistas para obtener réditos de corto plazo a costa de reducir una rentabilidad mayor en un horizonte de mediano y largo plazo.

\section{La evidencia de los EE.UU.}

Los EE.UU. sirven como un buen punto de referencia para analizar la experiencia de países que aceptan el lucro en la educación superior incluido el ámbito universitario. Allí, cualquier institución puede organizarse como mejor convenga a sus intereses y sus estudiantes acceder a créditos con subsidio estatal. En una apretada síntesis, se puede caracterizar la educación superior con fines de lucro en el país del norte como una oportunidad de acceso para grupos de la sociedad con énfasis en: minorías étnicas, con bajos niveles de ingreso familiar, más bien adultos, con preponderancia del sexo femenino, que ven dificultades de acceso en instituciones públicas o privadas sin fines de lucro y que habitualmente demandan una formación técnica profesional, en programas a distancia y no conducentes necesariamente a grados académicos.

Algunas cifras ${ }^{1}$ : los alumnos en instituciones con fines de lucro en programas de cuatro años pagan en promedio, descontadas las becas, $20 \%$ más que los estudiantes en "colleges" privados y $50 \%$ más en relación a los públicos. Ello, en alguna medida, porque disponen de menos recursos públicos y donaciones. El gasto relativo que se orienta a la instrucción es menor. Sus estudiantes exhiben tasas de endeudamientos y morosidad sustancialmente más altas. Las tasas de graduación en programas de cuatro años en dichas instituciones son solo de $22 \%$ de las respectivas cohortes, mientras las de establecimientos privados sin fines de lucro y públicos ascienden a $65 \%$ y $55 \%$, respectivamente. Sin embargo, las tasas de graduación en programas de dos años, que es donde se concentra la actividad de los programas con fines de lucro, es mayor, 58\%, respecto al $21 \%$ en instituciones públicas. Esto, a su vez, es coherente con las mayores tasas de retención de alumnos en estos programas cortos.

La preocupación por el endeudamiento de los estudiantes norteamericanos ha estado muy presente en la discusión pública y la más alta tasa de endeudamiento en programas con fines de lucro ha focalizado parte del debate en este tipo de instituciones. La administración de Obama ha declarado que pretende instalar nuevas regulaciones para

${ }^{1}$ Véase Kevin Kinser (2009). 
prevenir que las instituciones prometan a sus estudiantes más de lo que pueden entregar en competencias y habilidades laborales, lo que finalmente les impide pagar las deudas porque reciben bajos salarios. Una de las medidas propuestas es poner límites máximos de préstamos a los programas que actualmente tienen altas tasas de morosidad. Ello ha puesto la discusión del lucro en la primera línea de fuego, confrontando a connotados economistas como los premios Nobel de Economía Joseph Stiglitz y Gary Becker.

Joseph Stiglitz:

Las deficiencias en la regulación de colleges con fines de lucro les da espacios para explotar a los sectores de bajos ingresos quienes aspiran a ser parte del sueño americano. Estas instituciones han probado ser mejores para abusar que para ofrecer una educación valiosa y necesitan ser reguladas eficazmente ${ }^{2}$.

Gary Becker:

Desafortunadamente, varias propuestas para restringir los préstamos a estudiantes de bajos ingresos reflejan parcialmente el deseo del gobierno federal de atacar con dureza a las instituciones con fines de lucro. Sin embargo, ellas han jugado un rol significativo en el portafolio de opciones para dichos estudiantes, en especial para personas que trabajan y que son de mayor edad. Su capacidad para competir con entidades públicas y privadas sin fines de lucro, que reciben elevados subsidios, indica que entregan una educación de valor ${ }^{3}$.

\section{La evidencia de Chile}

La educación superior chilena ha mostrado notables avances en cobertura, entregando a vastos grupos de estudiantes las herramientas necesarias para ganarse la vida, lo que se refleja en altas tasas de rentabilidad privada, sin menospreciar el aporte a los estudiantes, en particular de las universidades, en la formación de valores, espíritu crítico y en el cultivo de un sentido ciudadano. Sin embargo, la heterogeneidad es alta y en muchos casos se observan ostensibles debilidades en calidad, ya sea

\footnotetext{
${ }^{2}$ Joseph Stiglitz (2012).

${ }^{3}$ Gary Becker (2012).
} 
en la formación técnica, profesional o universitaria, al amparo de una regulación defectuosa que ha permitido la creación de instituciones que no cuentan con las capacidades para brindar una educación habilitante para el mercado laboral y, a veces, tampoco para formar ciudadanos cultos.

Al calor del debate sobre las causas de estas limitantes surge siempre la crítica sobre las falencias del sistema, ya sea del aseguramiento de la calidad, la precariedad de la información, la falta de recursos y, en el último tiempo, el lucro. Pero, ¿es el lucro una de las causas de la mala calidad?

La reciente investigación de la Cámara de Diputados sobre el lucro en la educación superior, concluye que "no solo existe el lucro en la educación superior, sino que, además, no funciona todo el marco normativo que regula el sistema". La investigación habría sido una instancia valiosa para abordar el tema no solo desde el punto de vista del cumplimiento de la ley, sino a la luz de la experiencia comparada sobre el rol y aporte de las instituciones que estarían lucrando. En la práctica solo describe y contrapone latamente las diferentes visiones sobre el tema por medio de múltiples entrevistas, pero sin entregar una fundamentación clara que dé sustento a la conclusión final: "el lucro en la educación constituiría una especie de defraudación al estudiante, al Fisco y la sociedad, y la persona que incurra en esta conducta no puede seguir siendo prestadora de un bien social, que es la educación, porque causa un daño o perjuicio irreparable a la sociedad"4.

Así, más allá de que se declare que hay un incumplimiento de la ley, ¿cuál es el daño o perjuicio irreparable a la sociedad?, ¿es solo un daño a la confianza en las instituciones?, ¿podemos decir algo más?

A continuación se muestra un ejercicio ${ }^{5}$ que intenta caracterizar al sistema universitario chileno en base a un análisis comparado de universidades que pertenecen a diferentes categorías, utilizando indicadores sobre información financiera-contable, académicos y de costo-eficacia. La primera separación se hace a partir de un criterio de desarrollo institucional y orientación hacia la docencia e investigación. En nuestro país, algunas universidades pertenecen a un grupo con una clara orientación hacia la investigación y doctorados, y hay otras que son marcadamente docentes, admitiendo una interfaz de mayor o menor grado respecto a

${ }^{4}$ Informe Cámara de Diputados, junio 2012.

5 Realizado a partir de información pública contenida en los informes entregados por las universidades al Mineduc. 
tales atributos ${ }^{6}$. En nuestro análisis de las docentes se separa a las que han sido acreditadas institucionalmente y de entre ellas se identifica a ciertas universidades que podrían ser definidas por su finalidad hacia el lucro. Se parte del supuesto de que hay universidades que han formado sociedades comerciales relacionadas con los dueños o controladores de la universidad, las que serían elegibles para entrar en la categoría de fines de lucro. Esto implica dos prevenciones a tener en cuenta. La primera es que no hay evidencia de que lucran. Aquí el lucro se considera como una situación en que el excedente que queda de la actividad universitaria, una vez pagados todos los costos, no se reinvierte en la propia actividad universitaria sino que se extrae para pagar a los propietarios. En consecuencia, si las sociedades relacionadas reciben un pago por el servicio que prestan a la universidad, pero al mismo costo de oportunidad, en estricto rigor, no lucran. En cambio, si lucraran, el mecanismo para hacerlo es la formación de sociedades comerciales relacionadas, que reciben pagos por servicios prestados por sobre el mercado, generando un excedente o renta que se transfiere fuera del ámbito universitario. Es obvio que determinar con rigurosidad si hay o no lucro no es tarea sencilla. La segunda prevención es que no se cuenta con información validada sobre cuáles universidades han creado de facto una estructura corporativa cuyo fin pudiera ser la extracción de excedentes. El Mineduc entregó recientemente una versión oficial sobre las empresas que están relacionadas con universidades lo que da cuenta de que este fenómeno está más extendido de lo que se podría esperar ${ }^{7}$. Todas las universidades del CRUCH* y sobre el $90 \%$ de las privadas tienen sociedades relacionadas. Así, se contabilizan alrededor de 350 sociedades relacionadas. Cómo distinguir aquellas universidades que crean entidades relacionadas con el propósito de retirar excedentes de las que solo lo hacen por razones de otra índole como separar las actividades docentes y/o de investigación de la venta de servicios o el fomento de la innovación o realizar actividades de extensión y cuyos excedentes quedan en la matriz, ya está dicho, es tarea compleja que requiere información no disponible. Por lo tanto, el ejercicio consistió en seleccionar un conjunto de universidades privadas que, ya sea por ser de público conocimiento de haber participado en la venta

${ }^{6}$ Según se desprende del método de Reyes-Rosso (2011).

${ }^{7}$ Véase informe sobre Sociedades Relaciones Mineduc.

* CRUCH: Consejo de Rectores de las Universidades Chilenas, integrado por los rectores de las 25 universidades públicas del país. (N. del. E.) 
a consorcios internacionales de educación o cuyos controladores son conocidos empresarios y que cuentan con sociedades comerciales paralelas, se las define como instituciones que potencialmente podrían lucrar por medio del retiro de excedentes. Es un método, sin duda, con algún grado de arbitrariedad, pero creemos que los márgenes de error, si bien pueden existir, son reducidos.

El método entonces agrupa las universidades en cuatro categorías $^{8}$. (A) Universidades más complejas, acreditadas, que muestran una clara tendencia hacia la formación de capital humano avanzado y tienen varias líneas de investigación. Son 6 universidades y estudia allí el 20\% de los universitarios del sistema. (B) Universidades docentes con algunos postgrados y en algunos casos incipientes líneas de investigación, acreditadas y con sociedades comerciales sin el propósito de lucro. Son 30 universidades, públicas y privadas en las que estudia el 41\% de los universitarios. (C) Universidades docentes con algunos postgrados $\mathrm{y}$ en ciertos casos incipientes líneas de investigación, acreditadas y con sociedades comerciales susceptibles de perseguir el lucro. Son 15 universidades y estudia allí el 34\% de los alumnos. (D) Universidades docentes, no acreditadas. Son 6 universidades donde estudia el 5\% de los estudiantes.

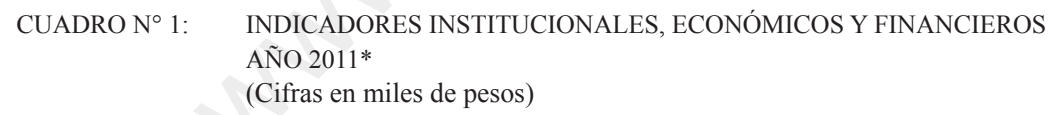

Grupo A Grupo B Grupo C Grupo D

$\begin{array}{lrrrr}\text { Activo fijo por alumno } & 5.583 & 3.064 & 1.041 & 618 \\ \text { Pasivos por alumno } & 3.546 & 1.588 & 1.656 & 2.518 \\ \text { Patrimonio por alumno } & 6.294 & 3.324 & 1.971 & 256 \\ \text { Gastos operacionales por alumno } & -6.627 & -2.897 & -2.444 & -2.883 \\ \text { Resultados del ejercicio por alumno } & 274 & 266 & 193 & -80 \\ \text { Inversiones del período por alumno } & 302 & 258 & 484 & -18 \\ \text { Donaciones período 2000-2011 por alumno } & 949 & 545 & 226 & 217 \\ \text { Aranceles promedios ponderados por } \mathrm{N}^{\circ} \text { de alumnos } & 2.877 & 2.083 & 2.504 & 1.781\end{array}$

* Información pública obtenida de los informes entregados por las universidades al Mineduc (www.mifuturo.cl)

${ }^{8}$ Véase Anexo 1. 
Los rasgos más marcados en el Cuadro $\mathrm{N}^{\circ} 1$ es que el grupo A de universidades de investigación es muy diferente al resto. Que los grupos B y C presentan similares características en cuanto a los pasivos, gastos operacionales y resultados del ejercicio. Las universidades $\mathrm{C}$ cuentan con menos activos fijos y patrimonio y han recibido menos donaciones, como era de esperar por su organización corporativa, pero generaron una mayor inversión durante el 2011. Respecto al grupo D, no acreditadas, la diferencia frente al resto es apreciable y revela que se trata de universidades con una situación económica financiera precaria. Tienen alto pasivo, bajo patrimonio, tuvieron en promedio resultados negativos y no hubo inversión neta en el ejercicio 2011.

Con respecto a algunos indicadores académicos (Cuadro $\mathrm{N}^{\circ} 2$ ) la comparación muestra que el grupo A se distingue del resto, especialmente en mayor puntaje PSU, menor porcentaje de alumnos de colegios subvencionados, mayor tasa de retención, menor tasa de alumnos por profesor, más académicos con postgrado y mayor porcentaje de carreras acreditadas. En tanto, al contrastar los grupos B y C, hay similitud en tasas de retención y participación de alumnos provenientes de colegios subvencionados, mientras que el grupo B presenta un mayor porcentaje promedio en la PSU, lo que puede explicarse porque las universidades públicas de la muestra cuentan con esquemas más atractivos de becas y créditos de carácter fiscal. También tienen un mayor porcentaje de académicos con postgrado. El grupo D tiene menores tasas de retención y un mayor porcentaje de estudiantes de colegios subvencionados.

\section{CUADRO N ${ }^{\circ}$ 2: $\quad$ INDICADORES INSTITUCIONALES, ACADÉMICOS}

Grupo A Grupo B Grupo C Grupo D

\begin{tabular}{|c|c|c|c|c|}
\hline $\begin{array}{l}\text { Puntaje promedio PSU } \\
\text { (ponderado por } \mathrm{N}^{\mathrm{o}} \text { de alumnos) }\end{array}$ & 649,20 & 547,52 & 519,01 & 492,21 \\
\hline $\begin{array}{l}\text { Tasa de retención al 2do año (cohorte 2008), } \\
\text { promedio del grupo }\end{array}$ & $75,0 \%$ & $64,3 \%$ & $63,4 \%$ & $51,8 \%$ \\
\hline $\begin{array}{l}\% \text { de alumnos provenientes de establecimientos } \\
\text { municipales y particulares subvencionados, } \\
\text { promedio del grupo }\end{array}$ & $72,5 \%$ & $83,2 \%$ & $83,7 \%$ & $89,0 \%$ \\
\hline $\begin{array}{l}\mathrm{N}^{\circ} \text { total de alumnos grupo/JCE } \\
\% \text { académicos con postgrado ponderado por }\end{array}$ & 19,23 & 29,01 & 39,26 & 25,54 \\
\hline $\mathrm{N}^{\circ}$ de alumnos & $58,5 \%$ & $41,4 \%$ & $27,9 \%$ & $\mathrm{~s} / \mathrm{i}$ \\
\hline $\begin{array}{l}\% \text { programas pregrado acreditados del grupo } \\
\text { ponderado por } \mathrm{N}^{\circ} \text { de carreras de pregrado del grupo }\end{array}$ & $42,4 \%$ & $15,8 \%$ & $5,4 \%$ & $\mathrm{~s} / \mathrm{i}$ \\
\hline
\end{tabular}

Fuente: Ministerio de Educación (www.mifuturo.cl). 
CUADRO $N^{\circ}$ 3: $\quad$ INDICADORES COSTO-EFICACIA POR CARRERA

\begin{tabular}{|c|c|c|c|c|c|}
\hline & $\begin{array}{c}\text { Arancel anual } \\
2011\end{array}$ & $\begin{array}{l}\text { Duración real } \\
\text { (años) }\end{array}$ & Costo total & $\begin{array}{l}\text { Ingreso promedio } \\
\text { Anual al } 4^{\circ} \text { año } \\
\text { titulación }\end{array}$ & $\begin{array}{l}\text { Años } \\
\text { recupe- } \\
\text { ración } \\
\text { costo total }\end{array}$ \\
\hline \multicolumn{6}{|c|}{ Agronomía } \\
\hline Grupo A & 3.043 .700 & 8,7 & 26.380 .881 & 11.205 .200 & 2,4 \\
\hline Grupo B & 2.284 .667 & 7,5 & 17.114 .289 & 10.500 .000 & 1,6 \\
\hline Grupo C & 2.466 .307 & 7,8 & 19.132 .033 & 8.721 .675 & 2,2 \\
\hline \multicolumn{6}{|c|}{ Arquitectura } \\
\hline Grupo A & 3.240 .870 & 7,9 & 25.620 .310 & 10.866 .202 & 2,4 \\
\hline Grupo B & 2.984 .250 & 8,5 & 25.301 .883 & 10.742 .956 & 2,4 \\
\hline Grupo C & 3.157 .284 & 8,0 & 25.237 .351 & 10.500 .000 & 2,4 \\
\hline \multicolumn{6}{|c|}{ Contador Auditor } \\
\hline Grupo A & 2.367 .818 & 6,9 & 16.437 .336 & 11.458 .493 & 1,4 \\
\hline Grupo B & 1.950 .832 & 7,0 & 13.559 .213 & 10.242 .918 & 1,3 \\
\hline $\begin{array}{l}\text { Grupo C } \\
\text { derecho }\end{array}$ & 1.682 .015 & 6,1 & 10.227 .316 & 11.765 .953 & 0,9 \\
\hline Grupo A & 3.126 .000 & 9,2 & 28.771 .431 & 20.679 .199 & 1,4 \\
\hline Grupo B & 2.523 .400 & 8,9 & 22.563 .383 & 16.199 .787 & 1,4 \\
\hline Grupo C & 3.093 .481 & 8,8 & 27.326 .712 & 16.500 .000 & 1,7 \\
\hline \multicolumn{6}{|c|}{ Enfermería } \\
\hline Grupo A & 2.608 .464 & 5,9 & 15.338 .859 & 12.860 .283 & 1,2 \\
\hline Grupo B & 2.325 .056 & 6,3 & 14.637 .398 & 11.930 .831 & 1,2 \\
\hline \multicolumn{6}{|l|}{ Grupo C } \\
\hline \multicolumn{6}{|c|}{ Ingeniería Civil Industrial } \\
\hline Grupo A & 3.533 .314 & 7,5 & 26.674 .151 & 19.425 .716 & 1,4 \\
\hline Grupo B & 2.587 .913 & 8,5 & 22.050 .546 & 16.283 .940 & 1,4 \\
\hline Grupo C & 3.286 .333 & 7,7 & 25.326 .456 & 16.500 .000 & 1,5 \\
\hline \multicolumn{6}{|c|}{ Ingeniería Comercial } \\
\hline Grupo A & 3.314 .428 & 6,5 & 21.510 .580 & 16.462 .354 & 1,3 \\
\hline Grupo B & 2.593 .985 & 7,1 & 18.359 .616 & 12.876 .828 & 1,4 \\
\hline Grupo C & 2.686 .372 & 6,4 & 17.316 .016 & 12.496 .563 & 1,4 \\
\hline \multicolumn{6}{|l|}{ Medicina } \\
\hline Grupo A & 4.260 .250 & 7,6 & 32.380 .506 & 22.500 .000 & 1,4 \\
\hline Grupo B & 4.179 .059 & 7,6 & 31.834 .010 & 21.601 .746 & 1,5 \\
\hline Grupo C & $\mathrm{n} / \mathrm{a}$ & & & & \\
\hline \multicolumn{6}{|c|}{ Periodismo } \\
\hline Grupo A & 2.577 .800 & 6,8 & 17.489 .379 & 9.090 .945 & 1,9 \\
\hline Grupo B & 2.678 .238 & 6,9 & 18.411 .889 & 8.505 .547 & 2,2 \\
\hline Grupo C & 3.111 .140 & 6,0 & 18.790 .529 & 7.500 .000 & 2,5 \\
\hline \multicolumn{6}{|c|}{ Trabajo Social } \\
\hline Grupo A & 2.328 .750 & 5,7 & 13.350 .195 & 7.500 .000 & 1,8 \\
\hline Grupo B & 1.793 .605 & 6,2 & 11.200 .991 & 7.500 .000 & 1,5 \\
\hline Grupo C & 1.865 .669 & 5,5 & 10.233 .260 & 7.069 .197 & 1,4 \\
\hline \multicolumn{6}{|c|}{ Promedio simple de las carreras seleccionadas } \\
\hline Grupo A & 3.040 .139 & 7,3 & 22.395 .363 & 14.204 .839 & 1,7 \\
\hline Grupo B & 2.590 .100 & 7,4 & 19.503.322 & 12.638 .455 & 1,6 \\
\hline Grupo C & 2.668 .575 & 7,0 & 19.198 .709 & 11.381 .673 & 1,7 \\
\hline
\end{tabular}


Otro punto de vista más focalizado es el costo-efectividad de las carreras (Cuadro $\mathrm{N}^{\circ} 3$ ) y consiste en analizar ocho carreras tradicionales de pregrado 9 . No hay información disponible sobre el grupo D que permita hacer un paralelo. La comparación considera las remuneraciones al cuarto año desde el egreso, el arancel y los años de estudio. Se advierte que entre los grupos $\mathrm{B}$ y $\mathrm{C}$ no hay apreciables diferencias en las remuneraciones de las carreras seleccionadas, si bien en el promedio simple de la muestra el grupo B exhibe una remuneración levemente mayor. En cuanto a años de estudio se comprueba que en todos los casos las carreras son largas en duración. Pero de las ocho carreras de la muestra la duración en el grupo $C$ es levemente inferior, 7 años de estudio, frente a 7,4 años en el grupo B. Lo anterior permite calcular el tiempo de pago del costo de las carreras de la muestra a partir de la remuneración percibida, bajo el supuesto de que dicha remuneración fuese la misma a lo largo del tiempo desde el egreso y no se pagaran intereses. En ese marco la remuneración financiaría el costo de las carreras de las universidades del grupo $\mathrm{B}$ y $\mathrm{C}$ en un periodo prácticamente idéntico (1,6 y 1,7 años, respectivamente).

\section{La prohibición del lucro}

La ley de universidades del año 1981 determinó que solo estaban permitidas las entidades que se organizaban como instituciones sin fines de lucro. La normativa legal no previó que la creación de sociedades comerciales paralelas, en especial aquellas con giro distinto al universitario propiamente tal y de propiedad de los mismos controladores de las universidades, en la práctica, daba espacios para la extracción de excedentes, es decir, lucrar. Hay un presunción obvia que este resquicio legal dio espacios para que empresarios y grupos económicos crearan sociedades comerciales paralelas para invertir en educación universitaria y rentabilizar su inversión, y, en mucho casos, retirar excedentes desde las universidades a través de diferentes esquemas financieros. Si fue correcta la decisión de prohibir el lucro desde el punto de vista del desarrollo del sistema universitario, sin poner restricciones a la formación de sociedades comerciales paralelas de los mismos dueños, abriendo así un flanco para una suerte de lucro encubierto, pero lucro al fin, es

\footnotetext{
${ }^{9}$ Véase www.mineduc.cl.
} 
una pregunta compleja aunque la evidencia presentada arroja algunas luces al respecto.

Una tesis muy difundida es que las instituciones que de hecho crearon sociedades comerciales para rentabilizar su inversión, lucrando del negocio universitario por medio del retiro de excedentes, defraudaron la fe pública, causando lo que la Comisión de la Cámara califica como un "daño irreparable a la sociedad". La comprobación de la validez de esa tesis tiene dos dimensiones, una simple en el sentido de que efectivamente se habría vulnerado, tal vez no la letra, pero sí el espíritu de la ley, porque posiblemente ha habido lucro encubierto mediante la transferencia de excedentes a las sociedades comerciales. Agrava la falta, sin duda, el hecho de que la condición de ser sin fines de lucro, exime a las universidades del pago de impuestos de primera categoría y de bienes raíces, además de existir una fuerte reducción del pago de impuestos por las donaciones.

Con todo, hay otra dimensión que no podemos soslayar y que aborda la interrogante desde el punto de vista de lo que ha sido el aporte que dichas instituciones han hecho al sistema universitario. Los antecedentes presentados anteriormente demuestran que un número muy significativo de las universidades con acreditación institucional y que han formado entidades comerciales relacionadas, tras lo cual puede haber sospecha de lucro, y que representan el 34\% del sistema, es decir, a 220 mil estudiantes, primero, exhiben indicadores contables que revelan una razonable fortaleza financiera, y segundo, indicadores académicos y de resultados no muy distintos a las entidades públicas y privadas sin fines de lucro que han sido acreditadas institucionalmente. Asimismo, hay un segundo grupo de universidades que no han pasado el tamiz de la acreditación institucional, que también podrían haber formado sociedades comerciales relacionadas a sus propietarios y que representan el 5\% del sistema. Si bien hay escasa información a la mano, los pocos datos insinúan que hay allí una preocupante precariedad financiera y académica.

\section{Universidades sin fines de lucro: ¿Cómo hacer cumplir la ley?}

Debe entenderse como lucro sancionable de acuerdo a la ley al retiro de excedentes o renta de las actividades universitarias, o sea de 
todas las actividades que se relacionan con el giro universitario, por medio de sociedades comerciales relacionadas y cuyo destino sean los propietarios o controladores. Es probable que exista un sinnúmero de casos que puedan estar en el borde de lo que se define como una actividad lucrativa no admisible. Con todo, hay situaciones que se exceptúan de esa definición y que corresponden a actividades legítimas que no contravienen ni la letra ni el espíritu de la ley. Son sociedades comerciales en muchos casos relacionadas con el giro universitario y otras que pueden estar más alejadas, pero que sean necesarias para generar nuevos ingresos que reinvertidos en la matriz potencian su proyecto educativo. A este respecto conviene recordar que el Servicio de Impuestos Internos ha mantenido la política de exigir que las universidades separen los negocios "lucrativos fuera de su giro", como es la expresión que se utiliza, con el propósito de transparentar tales actividades y forzar el pago de impuesto de primera categoría.

En consecuencia, los motivos para formar sociedades relacionadas pueden ser diversos. Hay sociedades que se constituyen para el fomento de la investigación e innovación productiva y que significan pagos a académicos que participan de tales actividades en forma directa o por medio de dividendos en sociedades anónimas donde tienen participación accionaria. En efecto, están los llamados "spin off" o empresas de innovación creadas mediante emprendimientos realizados por académicos de la propia universidad. En otros casos debe reconocerse que son actividades académicas que agregan valor, por ejemplo, nuevos descubrimientos que se traducen en patentes de invención, en que hay retornos al capital humano invertido y habitualmente también a la universidad que los acoge. Una situación similar se presenta en sociedades comerciales cuyo giro es universitario, por ejemplo, salud, en que se busca potenciar el desarrollo de campos clínicos para estudiantes de medicina y se requiere un socio estratégico para capitalizar y crecer. No distinto podría ser el caso de sociedades comerciales relativas a Centros de Formación Técnica, Institutos Profesionales o Colegios, que sí pueden constituirse con fines de lucro, pero cuyo objetivo respecto a ellos puede ser invertir y generar buena educación y que, además, pueden generar lazos académicos virtuosos, ya sea con programas de pedagogía en el caso de los colegios o alianzas estratégicas para facilitar la integración de dichos estudiantes a las universidades. Pero también es 
cierto que tales sociedades pueden ser instrumentales para retirar excedentes y defraudar la ley. Asimismo, es riesgoso que existan sociedades comerciales que reciben préstamos de la universidad, ya que se pueden establecer contratos financieros que permiten retirar excedentes, afectando patrimonialmente a la universidad ${ }^{10}$. Finalmente, están las sociedades comerciales que tienen la propiedad de los inmuebles, donde, a mi juicio, está el nudo gordiano o núcleo principal del problema porque ahí está uno de los principales activos estratégicos del proyecto educacional.

En el actual contexto de prohibición del lucro universitario, como se definió más arriba, hacer cumplir la ley, en la letra y en el espíritu, considerando los múltiples contratos con relacionados, supone analizar al menos dos opciones: la primera es prohibir dichos contratos. Hemos visto que los contratos con relacionados son la regla y muchas veces son necesarios para una mejor gestión y/o para estimular ciertas actividades académicas, por tanto la prohibición puede ser un camino que puede tener costos elevados. La segunda opción es normar estos contratos. El caso de mayor relevancia son los contratos de inmuebles destinados a la actividad universitaria y es donde habría que poner mayor atención Se ha planteado diseñar una transición de venta normada a las fundaciones o corporaciones universitarias de origen. De ser así, ésta tiene que ser por fuerza solo a la universidad de origen y sujeta a una regulación del precio de venta de los activos, porque de otro modo se presta a que los controladores liciten al mejor postor, por ejemplo, otra universidad, para subir el precio hasta el nivel monopólico que terminaría pagando la universidad instalada, que no puede arriesgarse a perder el inmueble donde estudian sus alumnos. Tarea nada de fácil, considerando las cuantiosas inversiones que han realizado las universidades privadas con sociedades comerciales y la complejidad de contar con valores referenciales de mercado. Hay que decidir qué precio fijar, ¿el precio de hoy?, ¿el histórico cuando se compró el inmueble? o ¿el valor potencial futuro? Por cierto, con el fin de desmontar la estructura de sociedades relacionadas y cortar la relación con los inmuebles donde residen los estudiantes, existe como alternativa a la venta, primero,

${ }^{10} \mathrm{Al}$ respecto, llama la atención el que las universidades del Grupo C presentan cifras mayores de la cuenta "Otros activos", que podrían obedecer a préstamos a sociedades relacionadas. 
transferir los bienes a un tercero, o bien, ceder el control, ya sea de la universidad o de las sociedades comerciales, igualmente, a un tercero distinto de los relacionados. El problema de esas soluciones es que la venta de los activos a un tercero reproduce e incluso empeora las dificultades por una triangulación evidente: será a un precio monopólico el mismo que pagará la universidad cuando deba negociar entre la espada y la pared con el tercero por el arriendo de los inmuebles. Por otra parte, la cesión del control — sin venta- peca de la misma falla que se busca corregir: como la propiedad del capital sigue en manos del relacionado, es difícil que no exista una captura de quien oficia en la práctica como representante del principal respecto a las decisiones más relevantes que comprometen su patrimonio. La economía política que hay detrás de la prohibición y consecuente venta se percibe compleja por el engorroso proceso que supone desmontar la actual estructura de sociedades comerciales sobre los inmuebles.

La otra opción es permitir tales sociedades y normar los contratos de arriendo, lo que, a mi juicio, tampoco es sencillo, pero presenta menos dificultades prácticas. En teoría, ambos métodos están interrelacionados porque el valor de un activo es el valor presente del flujo de las rentas netas que generará ese activo en el futuro. Sin embargo, hay mucha evidencia de que los precios de los activos inmobiliarios suelen fluctuar bastante más que los valores de arriendo y suelen alejarse con facilidad de los "fundamentos" económicos. Entonces será más fácil ponerse de acuerdo en valores de arriendo que en precios de activos.

Ésta es la opción de la cual se hace cargo el proyecto de ley que crea la Superintendencia de Educación Superior. Se señala que las universidades pueden celebrar contratos con entidades relacionadas, solo a condición de que sea a valores comparables de mercado y se establecen resguardos como la presencia de directores independientes en las juntas directivas para cautelar el cumplimiento de dicho objetivo. En el caso de la infraestructura, el precio resultante en este contexto debiera ser regulado o de otro modo la universidad se expone a pagar un arriendo por un inmueble ya construido y que goza de una posición monopólica. En efecto, es obvio que el recinto, una vez construido, es el mejor ubicado para realizar las actividades universitarias de su arrendatario relacionado y eso se podría reflejar en una renta monopólica. En consecuencia, para evitar que se defraude la normativa que prohíbe el lucro en universidades 
ya instaladas, no basta con incorporar directores independientes como garantes para visar esas transacciones, como dispone el proyecto de ley; debiese ser exigible además la contratación de entidades especializadas autónomas para fijar adecuadamente estos precios de transferencia.

\section{En suma}

El lucro ha sido estigmatizado como una de las causas centrales de la baja calidad. Sin embargo, la calidad no es un atributo asociado a aquellas universidades que se identifican como sin fines de lucro, sean de carácter público o privado. Un vasto número de universidades privadas "con fines de lucro" muestran indicadores respetables, o si se quiere, no sustantivamente distintos del resto. Y sobre la tesis de que se ha fallado en el control de calidad porque hemos tenido una acreditación laxa, que comparto sin duda, agrego otra tesis en esa línea. El problema tal vez es anterior a la acreditación: haber dado licencia y autonomía a universidades que no daban el ancho para merecer su condición de tales y que ni siquiera han sido capaces de recibir una acreditación mínima de dos años como dispone la ley.

El cumplimiento de la ley vigente que prohíbe el lucro, no es una opción, es una condición para participar lealmente del sistema, pero el control y fiscalización del lucro universitario debe hacerse con cautela. Hacerlo de modo de separar la paja del trigo. No imponer una regulación que peque de poco inteligente y que suprima las sociedades relacionadas so pretexto de cortar de raíz el problema, porque podemos arrancar "buen trigo": el modelo de sociedades relacionadas pueden ser virtuoso para la gestión universitaria y la promoción de desarrollos innovadores en educación, ciencia y tecnología.

El tema principal es la relación con sociedades inmobiliarias. Hay que pensar bien qué se hace. Si hubiese que ponerse en un escenario base cero, tipo año 1981, y si estamos convencidos que el lucro no debe existir, entonces lo más sensato sería prohibir este tipo de relación. No es indispensable crear una sociedad inmobiliaria paralela a la universidad para que la universidad funcione. El problema es que estamos en el 2012, por lo tanto, un mínimo de pragmatismo sugiere ser cauto y ponderar los efectos de forzar la venta de los inmuebles frente a la alternativa de regular solo los contratos de arriendo. 


\section{ANEXO $1^{1}$}

\section{Categoría (A): Universidades de investigación y doctorados}
1. Universidad de Chile
4. Universidad de Santiago de Chile
2. P. Universidad Católica de Chile
5. P. Universidad Católica de Valparaíso
3. Universidad de Concepción
6. Universidad Austral de Chile

\section{Categoría (B) y (C): Universidades acreditadas}

1. Universidad Católica del Norte

2. Univer. Acad. de Humanismo Cristiano

3. Universidad Adolfo Ibáñez

4. Universidad Adventista de Chile

5. Universidad Alberto Hurtado

6. Universidad Arturo Prat

7. Universidad Autónoma de Chile

8. Universidad Bernardo O'Higgins

9. Univer. Católica Cardenal Silva Henríquez

10. Univer. Católica de la Stma. Concepción

11. Universidad Católica de Temuco

12. Univer. de Playa Ancha de Cs. de la Educ.

13. Universidad de Talca

14. Universidad de Tarapacá

15. Universidad de Valparaíso

16. Universidad de Viña del Mar

17. Universidad del Bío-Bío

18. Universidad del Desarrollo

19. Universidad del Mar

20. Universidad del Pacífico

21. Universidad Diego Portales

22. Universidad Finis Terrae

23. Universidad Católica del Maule
24. Universidad Central de Chile

25. Universidad de Antofagasta

26. Universidad de Artes y Cs. Sociales Arcis

27. Universidad de Atacama

28. Universidad de La Frontera

29. Universidad de La Serena

30. Universidad de Las Américas

31. Universidad de Los Andes

32. Universidad de Los Lagos

33. Universidad de Magallanes

34. Universidad Gabriela Mistral

35. Universidad I. de Cs. y Tecnología, Unicit

36. Universidad Internacional Sek

37. Universidad Mayor

38. Universidad Metrop. de Cs. de la Educación

39. Universidad Nacional Andrés Bello

40. Universidad San Sebastián

41. Universidad Santo Tomás

42. Universidad Técnica Federico Santa María

43. Universidad Tecnológica de Chile Inacap

44. Universidad Tecn. Metropolitana

45. Universidad Ucinf

\section{Categoría (D): Universidades no acreditadas}

1. Universidad Pedro de Valdivia

2. Universidad Miguel de Cervantes

3. Universidad de Artes, Cs. y Com.-Uniacc
4. Universidad Bolivariana

5. Universidad de Los Leones

6. Universidad de Aconcagua

${ }^{1}$ Las universidades de las categorías (B) y (C) no se identifican aquí por separado ya que según la clasificación propuesta en la sección 3, las universidades incluidas en la categoría $(C)$ corresponden a aquellas que, a mi juicio, tienen vínculos con sociedades comerciales susceptibles de perseguir lucro y, por tanto, de vulnerar la ley. 


\section{ANEXO 2: INDICADORES INSTITUCIONALES POR GRUPO}

(Cifras en miles de pesos, 2011)

Grupo A Grupo B Grupo C

Grupo C

Grupo D

(6)

(30)

(15)

(15)

(6)

Acred, $\geq 5$ Acred, $<5$

años (4) años (11)

\begin{tabular}{|c|c|c|c|c|c|c|}
\hline Activo fijo por alumno & 5.583 & 3.064 & 1.041 & 2.095 & 504 & 618 \\
\hline Otros activos por alumno & 1.280 & 459 & 1.230 & 1.546 & 1.069 & 125 \\
\hline Pasivos por alumno & 3.546 & 1.588 & 1.656 & 2.158 & 1.400 & 2.518 \\
\hline Patrimonio por alumno & 6.294 & 3.324 & 1.971 & 3.345 & 1.270 & 256 \\
\hline Ingreso operacional por alumno & 6.833 & 3.084 & 2.644 & 3.825 & 2.042 & 2.874 \\
\hline Gastos operacionales por alumno & -6.627 & -2.897 & -2.444 & -3.437 & -1.937 & -2.883 \\
\hline Resultados del ejercicio por alumno & 274 & 266 & 193 & 421 & 76 & -80 \\
\hline EBITDA por alumno & 519 & 328 & 349 & 622 & 210 & 153 \\
\hline Inversiones del período por alumno & 302 & 258 & 484 & 663 & 392 & -18 \\
\hline Donaciones período $2000-2011$ por alumno & 949 & 545 & 226 & 409 & 125 & 217 \\
\hline \multicolumn{7}{|l|}{ Donaciones 2000-2011 } \\
\hline $\mathrm{N}^{\circ}$ total de universidades & \multicolumn{2}{|c|}{17.399 .6823 .741 .201} & \multicolumn{2}{|c|}{1.929 .2074 .985 .793} & 993.104 & 409.293 \\
\hline Aranceles prom. ponderados por $\mathrm{N}^{\circ}$ de alumnos & 2.877 & 2.083 & 2.504 & 3.169 & 2.164 & 1.781 \\
\hline $\mathrm{N}$ de alumnos grupo $/ \mathrm{N}^{\circ}$ de carreras de pregrado & 246,72 & 106,37 & 92,60 & 165,56 & 75,60 & $\mathrm{~s} / \mathrm{i}$ \\
\hline Puntaje promedio PSU (pond. por $\mathrm{N}^{\mathrm{o}}$ de alumnos) & 649,20 & 547,52 & 519,01 & 570,06 & 498,18 & 492,21 \\
\hline $\begin{array}{l}\text { Tasa de retención al } 2 \text { do año (cohorte 2008), } \\
\text { promedio del grupo }\end{array}$ & $75,0 \%$ & $64,3 \%$ & $63,4 \%$ & $69,9 \%$ & $60,6 \%$ & $51,8 \%$ \\
\hline $\begin{array}{l}\% \text { de alumnos provenientes de est. municipales, } \\
\text { promedio del grupo }\end{array}$ & $28,9 \%$ & $32,0 \%$ & $26,9 \%$ & $19,8 \%$ & $29,1 \%$ & $36,4 \%$ \\
\hline$\%$ de alumnos provenientes de est. particulares & & & & & & \\
\hline subvencionados, promedio del grupo & $43,7 \%$ & $51,2 \%$ & $56,8 \%$ & $45,2 \%$ & $60,2 \%$ & $52,6 \%$ \\
\hline$\%$ de alumnos provenientes de est. municipales y & & & & & & \\
\hline particulares subvencionados, promedio del grupo & $72,5 \%$ & $83,2 \%$ & $83,7 \%$ & $65,0 \%$ & $89,3 \%$ & $89,0 \%$ \\
\hline $\mathrm{N}^{\circ}$ de carreras de pregrado/ $\mathrm{N}^{\circ}$ de universidades & 90,33 & 87,90 & 149,81 & 113,25 & 176,73 & $\mathrm{~s} / \mathrm{i}$ \\
\hline $\mathrm{N}^{\circ}$ total de alumnos grupo/JCE & 19,23 & 29,01 & 39,26 & 34,97 & 41,89 & 25,54 \\
\hline $\mathrm{JCE} / \mathrm{N}^{\circ}$ total de carreras de pregrado del grupo & 12,83 & 3,76 & 2,36 & 4,73 & 1,80 & $\mathrm{~s} / \mathrm{i}$ \\
\hline $\begin{array}{l}\mathrm{N}^{\circ} \text { total doctorados acreditados } / \mathrm{N}^{\circ} \text { total de } \\
\text { universidades del grupo }\end{array}$ & 18,50 & 0,76 & 0,19 & 0,75 & 0,00 & 0,00 \\
\hline$\%$ académicos con postgrado ponderado por & & & & & & \\
\hline $\mathrm{N}^{\circ}$ de alumnos & $58,5 \%$ & $41,4 \%$ & $27,9 \%$ & $29,8 \%$ & $27,1 \%$ & $\mathrm{~s} / \mathrm{i}$ \\
\hline$\%$ programas pregrado acreditados ponderado por & & & & & & \\
\hline $\mathrm{N}^{\circ}$ de carreras de pregrado del grupo & $42,4 \%$ & $15,8 \%$ & $5,4 \%$ & $8,8 \%$ & $4,0 \%$ & $\mathrm{~s} / \mathrm{i}$ \\
\hline $\mathrm{N}^{\circ}$ años promedio acreditación carreras de & & & & & & \\
\hline pregrado ponderado por $\mathrm{N}^{\circ}$ de carreras de pregrad & 4,93 & 3,20 & 2,79 & 3,42 & 2,54 & $\mathrm{~s} / \mathrm{i}$ \\
\hline
\end{tabular}




\section{REFERENCIAS BIBLIOGRÁFICAS}

Becker, Gary. Becker-Posner Blog, junio, 2012.

Cámara de Diputados de Chile. Informe Comisión Investigadora sobre el Funcionamiento de la Educación Superior. Junio, 2012.

Comisión de Financiamiento Estudiantil para la Educación Superior. "Análisis y Recomendaciones para el Sistema de Financiamiento Estudiantil". Marzo, 2012.

Fontaine T., Arturo. "Contra la Visión Fabril de la Educación: ¿Universidades con Fines de Lucro?”. Ciper, 4/8/2012. [Versión revisada en Estudios Públicos, 127 (invierno 2012)].

Kinser, Kevin. "Access in US Higher Education: What Does the ForProfit Sector Contribute?". Program for Research on Private Higher Education, University at Albany, Working Paper Series $N^{\circ} 14$ (marzo 2009).

Peña, Carlos. Columna "Impedir el Lucro". El Mercurio de Santiago, julio 2012.

- Cartas. El Mercurio de Santiago, julio-agosto 2012.

Reyes, Claudia y Pedro Pablo Rosso. "Una Nueva Clasificación de las Universidades Chilenas". Inédito.

Stiglitz, Joseph. "For Profit Colleges Exploit those at the Bottom". The Huffington Post, junio 2012.

Williamson B., Carlos y José Miguel Sánchez C. "Financiamiento Universitario: Principios Básicos para el Diseño de una Política Pública en Chile". Temas de la Agenda Pública. Vicerrectoría de Comunicaciones y Asuntos Públicos, P. Universidad Católica de Chile, 2009.

Williamson B., Carlos. Columna "El Lucro en el Sistema Universitario". El Mercurio de Santiago, agosto de 2012.

- Columna "Universidades: ¿Sin Fines de Lucro?”. El Mercurio de Santiago, febrero de 2005.

- Cartas. El Mercurio de Santiago, agosto de 2012. 


\title{
LUCRO, UNIVERSIDAD Y FILANTROPÍA*
}

\author{
Arturo Fontaine \\ Centro de Estudios Públicos
}

\begin{abstract}
¿Existen universidades que lucran en Chile, pese a la ley? Creo que todos sabemos que es así. La majamama de universidades sin fines de lucro que al mismo tiempo tienen fines de lucro ejerce un efecto corruptor de la filantropía y desprestigia al empresariado. ¿Para qué donar a una universidad sin fines de lucro si la de al lado tiene utilidades y sus controladores prosperan con ellas?

Las universidades con fines de lucro en Estados Unidos y en Brasil, países donde hoy son legales, representan un capitalismo mercantilista. Los estudios más recientes indican que en EE.UU. esos planteles son más caros y de peor calidad, sus titulados tienden a quedar cesantes y más endeudados que los de universidades comparables de naturaleza pública y sin fines de lucro. Hay 30 fiscales generales en EE.UU. investigando fraudes y delitos de universidades con fines de lucro. Las enormes asimetrías de información entre el alumno y la universidad, las dificultades para medir y evaluar una universidad, lo costoso que es volverse a educar (irreversibilidad del proceso), unidos al fin de lucro hacen tentador explotar esas asimetrías engañando a los estudiantes.

En EE.UU., a su vez, universidades como John Hopkins, Cornell, Chicago, Stanford, Yale, Princeton, Harvard, Columbia son instituciones privadas sin fines de lucro, creadas y sostenidas por el mecenazgo empresarial y aportes del Estado. Es frecuente que la matrícula que pagan sus alumnos no signifique más de un $20 \%$ de sus ingresos. No cabe duda que la filantropía en ese país ha mostrado que en los empresarios puede haber generosidad, grandeza, y eso le ha dado un rostro más humano al capitalismo. La filantropía es una mezcla público-privada surgida al interior del capitalismo norteamericano, aunque no ha sido fácil de exportar.
\end{abstract}

Arturo Fontaine. Escritor, director del Centro de Estudios Públicos, profesor del Departamento de Filosofía de la Universidad de Chile. Dirección electrónica: afontaine@cepchile.cl.

Agradezco la colaboración y comentarios de Joaquín Trujillo.

* Exposición en el Seminario "Lucro y Universidad", realizado el 28 de agosto de 2012 en el CEP. Véanse en esta misma edición las ponencias de Carlos Peña, Carlos Williamson y Ricardo Paredes. (N. del E.) 
Es en las universidades públicas y sin fines de lucro donde se está dibujando el futuro de nuestro país. ¿Queremos que se desarrolle en nuestro país una cultura de la filantropía en el campo de la cultura, o queremos que eso sea solo tarea (y prerrogativa) del Estado? Porque la gracia de la filantropía es que fomente la diversidad y el pluralismo en la cultura. Si eso no ocurre, pierde sentido.

$\mathrm{L}$ las clínicas, ni en los colegios, ni en la construcción de viviendas sociales, situaciones todas diferentes y permitidas por la ley. La discusión de esta tarde es el lucro en la universidad que la ley en Chile prohíbe.

¿Existen universidades que lucran en Chile, pese a la ley? Creo que todos sabemos que es así. Hay resquicios. El viernes 24 recién pasado se publicó en El Mostrador y en Ciper una declaración pública de Patricio Basso, quien el miércoles 22 había sido despedido de su cargo de secretario ejecutivo de la Comisión Nacional de Acreditación (CNA). Patricio Basso fue quien denunció a la Contraloría los contratos que tenía con la Universidad del Mar el presidente de la CNA, Eugenio Díaz. El conflicto de interés entre quien debe acreditar una universidad y le presta a su vez servicios a dicha universidad es evidente. Patricio Basso fue quien informó este año a través de oficios reservados al Ministerio de Educación de traspasos de dinero sin intereses desde la Uniacc y desde la Universidad Santo Tomás a instituciones relacionadas con fines de lucro. El Ministerio, como corresponde, está investigando estas denuncias. Pero quien las hizo ya no está ni estará más en la CNA.

José María Lemaitre, ex secretaria técnica de la CNA, declaró a Ciper: "[...]Tras una de las compras que hizo el consorcio Laureate, alguien del Consejo le preguntó a un representante de ellos cómo iban a recuperar la enorme inversión que habían hecho. Y el representante de Laureate dijo: 'La inversión está recuperada porque al comprar una universidad como esta, que tiene una escuela de medicina, que tiene esto y lo otro y lo demás allá, las acciones de Laureate subieron en tantos puntos, y con eso ya se recuperó la inversión' " (Ciper, 24/8/11).

Laureate Education Inc. tiene once universidades en Brasil, siete en España, tres en México, tres en China, una en Indonesia, una en 
Malasia, todas abiertamente con fines de lucro. ¿Y las seis que tiene en Chile son un proyecto filantrópico? En total, tiene 60 universidades en 29 países y 740.000 estudiantes. ¿Y solo en Chile sus universidades no tienen fines de lucro? El consorcio que controla Laureate es liderado por KKR de Henry Kravis, uno de los más importantes inversionistas de Wall Street, y está integrado también por Citigroup Private Equity, S.A.C. Capital Management LLC, SPG Partners, Bregal Investments, Caisse de depot et placement du Québec, Sterling Capital, Southern Cross Capital, entre otros. ¿Por qué en Chile esta súbita filantropía universitaria? En su sección de responsabilidad social la empresa señala que ha donado más de diez millones de dólares a diversas instituciones sin fines de lucro de distintos países. Curiosamente no figura ninguna donación hecha a universidades chilenas. En cambio sí es público y notorio que hace poco Mr. Kravis donó a Columbia University, donde se educó, cien millones de dólares de su patrimonio personal.

En un artículo que llamó "Penumbra en la Universidad", publicado en 2004, el reconocido biólogo y ex rector de la Universidad Católica, Juan de Dios Vial Correa, planteó las cosas de este modo: "Hubo una proliferación desordenada de universidades estatales, y eso es, por supuesto, responsabilidad directa del Estado". Vial Correa se refiere a las sedes de la Universidad de Chile que fueron transformadas durante la dictadura de Pinochet en universidades independientes, con financiamiento insuficiente y que fueron empujadas a operar como si se tratase de universidades con fines de lucro, cuyos ingresos debían provenir, en importante medida, de la matrícula de los alumnos y del "autofinanciamiento". Lo que hicieron muchas de ellas, entonces, fue expandir la cobertura aunque fuera a costa de la calidad. Esta mala práctica incluso se acentuó durante los gobiernos de la Concertación. Es en ellas donde se concentran los malos resultados de las universidades del CRUCH*.

Pero el Estado "tuvo también una responsabilidad indirecta al establecer reglas de juego para el desarrollo de las universidades privadas a las que no se les pedía que mostraran siquiera un solo profesor universitario de verdad. Se suponía que ellas iban a competir por la calidad de sus servicios 'universitarios', pero basta con mirar cada año las Guías de Admisión para comprobar la inmensa oferta que se hace de carreras y programas que de universitario tienen solo el nombre. Supongo que

* CRUCH: Consejo de Rectores de las Universidades Chilenas, integrado por los rectores de las 25 universidades públicas del país. (N. del E.) 
se pensaba que el hecho de que la ley prescribiera que las universidades no iban a tener fines de lucro, había de servir para alejar de ese terreno a quienes no tuvieran un primario y auténtico interés en la cultura. Pero los hechos han venido a aventar también esa ilusión. Hay inversionistas extranjeros que ponderan públicamente los atractivos del 'mercado de Educación Superior' en Chile, y en consecuencia se transan universidades privadas en nuestro país en sumas tan elevadas que la pretensión de que no tienen fines de lucro es simplemente risible. Aun más, se conoce bien el sistema de combinar una universidad que no genera utilidades con una inmobiliaria que sí las genera y que arrienda sus locales a la Universidad, con lo cual el conjunto se transforma en un paquete económicamente tentador" (Vial Correa, La Segunda, 19/8/2004).

Tenemos en Chile una situación jabonosa. Uno podría presumir que, en la práctica, hay empresas comerciales - algunas de las cuales se transan en Wall Street- que se enmascaran y simulan ser instituciones sin fines de lucro. Muchas de nuestras universidades son negocios camuflados. La institución sin fines de lucro es la contracara de una con fines de lucro. En el escenario del teatro, entonces, están la formación de profesionales universitarios, con togas y birretes que hacen pensar en las películas de Harry Potter y, por supuesto, los consiguientes beneficios tributarios (no hay impuesto a la renta, ni IVA, ni contribución de bienes raíces y sí donaciones con beneficios tributarios y alumnos con financiamiento estatal). Y detrás del escenario, en bambalinas, el negocio encubierto.

Chile no merece esto. La juventud chilena no merece esto. Ha llegado la hora de ponerle fin a esta comedia. Necesitamos prohibiciones simples y claras que impidan las operaciones de los controladores de las universidades con empresas relacionadas y se anticipen a los conflictos de interés.

Y, por supuesto, podemos permitir que existan universidades con fines de lucro, pero que paguen sus impuestos como cualquier empresa comercial y estén sometidas a un estatuto jurídico propio que hay que estudiar con cuidado.

Pero lo decisivo para el país no está en ellas. Lo decisivo es potenciar las universidades públicas y privadas sin fines de lucro. Eso requiere que el Estado invierta en dichas universidades para mejorar su docencia y su investigación. El positivo aumento de la cobertura, unido al crecimiento de universidades con fines de lucro en Chile, como en 
Brasil, probablemente se debe, en buena medida, a que el Estado no ha invertido todo lo que debe en la educación. Pero no nos confundamos: es, en general, en las universidades públicas y sin fines de lucro donde se va dibujando el futuro de Chile.

\section{2}

Quisiera aproximarme al tema desde otro ángulo: ¿Queremos que haya universidades sin fines de lucro o no? ¿Queremos que se desarrolle una cultura de la filantropía en el campo de la cultura o queremos que eso sea solo tarea del Estado? Porque la mezcolanza que he descrito corroe la confianza que hace posible que surja una cultura de la filantropía. La desconfianza que produce es tal que daña el prestigio del empresariado, deslegitimando el capitalismo. Los gobiernos, entonces, retiran los beneficios tributarios y concentran el control de la cultura. Porque la gracia de la filantropía es que fomente la diversidad y el pluralismo en la cultura. Si eso no ocurre, pierde sentido.

¿Para qué donar a una universidad sin fines de lucro si la de al lado tiene utilidades y sus controladores prosperan gracias a ella? ¿No hace el loco un rector que solicita dinero como donación para un proyecto si su competidor no sólo no requiere donaciones sino que obtiene utilidades? ¿Qué pensará de él el potencial donante? ¿No lo mirará como a un leso incompetente? ¿De cuándo acá un empresario le pide a otro una donación para su negocio?

Y mirado desde el Estado: ¿Por qué el Gobierno va a sacrificar parte de lo que recauda para que asignen ese dinero personas que a la hora de hacerlo, por ejemplo, no valoran la calidad de la universidad y su importancia para el país y sólo se guían por criterios ideológicos o religiosos? ¿Por qué darles beneficios tributarios a empresas lucrativas que deberían estar pagando impuesto a la renta?

El negocio que se presenta como filantropía es como una compraventa que se hace pasar por regalo. Empequeñece y envilece a quien lo da.

Esta majamama de universidades sin fines de lucro que, al mismo tiempo, tienen fines de lucro, que son y no son, que son lo que no son y no son lo que son, tiene un efecto corruptor de la filantropía.

¿Es quizás que nuestra sociedad no puede cultivar la filantropía, no sabe hacerlo, o tal vez muchos de nuestros empresarios, en el fondo, 
no creen en ella? ¿Será que algunos de nuestros economistas - que han sido sus profesores - piensan que el mero crecimiento económico genera y consolida instituciones capitalistas, las que se sostienen por esa sola causa de manera mecánica? ¿Será que, sin saberlo, quizás, son materialistas históricos, cándidos y desaprensivos discípulos de Karl Marx?

Si Putnam, si Douglass North, si Acemoglu en su libro reciente (Acemoglu y Robinson, 2012), tienen razón, la cosa es más bien al revés: son las instituciones socioeconómicas y políticas, que Acemoglu llama "inclusivas", las que generan el crecimiento económico sostenido. Esas instituciones surgen de una cultura inclusiva y desde allí se legitiman. El crecimiento económico las refuerza y se produce, así, un círculo virtuoso. Lo que nos hace falta es una cultura universitaria inclusiva y meritocrática. De allí la importancia central que le atribuyo al fortalecimiento de la educación pública. La filantropía puede hacer una contribución muy importante al país si asume ese desafío en lugar de concentrarse en proyectos exclusivistas de menor alcance republicano.

Sin embargo, tenemos una cierta tradición filantrópica: el Parque de Lota, el Parque Forestal, el Parque O'Higgins, el Palacio Cousiño son donaciones al país de la familia Cousiño. Y las hay en muchas otras áreas. En el campo universitario, la Universidad de Concepción, la Austral, la Federico Santa María, la Católica son universidades privadas sin fines de lucro. Y, más recientemente, la Adolfo Ibáñez, la Portales, la Finis Terrae, los Andes, la Padre Hurtado...

No cabe duda de que la filantropía en Estados Unidos ha mostrado que en los empresarios puede haber, de veras, generosidad, puede haber grandeza. Y eso le ha dado un rostro más humano al capitalismo.

"La caridad había sido para los necesitados, la filantropía sería para la humanidad", escribe Olivier Zunz (Zunz, 2012, loc. 240). Éste es un primer distingo que se desprende de la experiencia de Estados Unidos. Como vio ya Tocqueville, el sistema americano depende mucho del "arte de la asociación" y la filantropía es una expresión de esa capacidad de servir causas comunes desde la iniciativa privada.

Las instituciones sin fines de lucro son la expresión jurídica de un distingo esencial: un contrato no es lo mismo que una donación. Las investigaciones de Marcel Mauss encontraron esta distinción en pueblos muy primitivos. Y aunque a veces la diferencia no sea obvia, creo que todos nos damos cuenta que no es lo mismo comprar una botella de 
vino que recibir de regalo una botella de vino. Así como no es lo mismo para una mujer vender una noche de amor que regalarla. ¿Les parece razonable esta distinción o será una distinción conceptual romántica? Yo creo en esa diferencia. Para mí es una distinción sin la cual no podría imaginarme como ser humano. La amistad es un regalo, como lo es, por supuesto, el amor. "Por muy egoísta que se suponga al hombre, hay evidentemente en su naturaleza algunos principios que lo hacen interesarse en la suerte de los demás, y que hace que su felicidad sea necesaria para él, aunque no obtenga nada de ello, salvo el placer de contemplarla". Acabo de citar a Adam Smith (The Theory of Moral Sentiments, Parte I, sección I, capítulo 1, "Of Simpathy") Ésta es la raíz de la filantropía.

La filantropía norteamericana moderna comienza después de la Guerra Civil y se consolida a comienzos del siglo XX. John Hopkins, Ezra Cornell, Leland Stanford y John D. Rockefeller fundan las célebres universidades de John Hopkins, Cornell, Stanford y Chicago. Su proyecto es modernizar la vida universitaria, desarrollar las ciencias, las humanidades y las profesiones universitarias con rigor académico y sin la tutela de las órdenes religiosas. Porque hasta ese momento las donaciones estaban muy ligadas a la religión y la ayuda a los pobres, lo cual tiene un carácter más exclusivista y privado. Lo nuevo fue el enfoque republicano, progresista y secular. Universidades más tradicionales como Harvard, Yale, Princeton, Columbia, entre otras, se incorporan algo más tarde a esta misma visión. Por cierto, también se nutren hasta hoy de donaciones. Universidades como Stanford, Yale, Harvard, Columbia obtienen de la matrícula de sus estudiantes menos del $20 \%$ de su presupuesto. El resto proviene de donaciones y de aportes del Estado. Incluso en muchas buenas universidades estatales sucede algo parecido. Por ejemplo, Stony Brook, una universidad estatal más bien pequeña, obtiene el 18\% de sus recursos de la matrícula de los alumnos.

Por supuesto, la filantropía va mucho más allá de lo universitario: la salud, la beneficencia, la religión. La National Gallery de Washington es una donación de la familia Mellon, por ejemplo. Imaginen lo que significan Peggy Guggenheim y el Museo Guggenheim — hoy en una serie de ciudades del mundo- para la historia del arte del siglo XX. La Carnegie Institution for Science, para dar otro ejemplo, está aportando 59,2 millones de dólares a la construcción del Giant Magellan Telescope en construcción cerca de La Serena y que será lo más avanzado del mundo en su tipo. 
El modelo para los filántropos norteamericanos fue el mecenazgo de la nobleza burguesa de las ciudades italianas que financiaron el Renacimiento en Florencia, en Siena, en Milán, en Roma. Los Medici eran banqueros. Una figura central en esta transformación en Estados Unidos será John D. Rockefeller, que lidera, de algún modo, este proceso y dedica su vida entera a construir una cultura de la filantropía.

Porque la filantropía no es solo donación privada. Es, también, un beneficio tributario que el Estado concede al que dona en ciertos ámbitos. La legislación, entonces, fue modificada $-\mathrm{y}$ en esto Rockefeller juega un papel importante - para estimular el compromiso privado con causas de bien general. La filantropía es una mezcla público-privada surgida al interior del capitalismo norteamericano y que no ha sido fácil exportar con éxito. Al ayudar a los demás, me ayudo. Hay algo de eso, creo. No hace mucho un grupo de 40 grandes empresarios liderados por Warren Buffett y Bill Gates se comprometieron a donar el 50\% de sus fortunas. Salta a la vista el tremendo poder legitimador del capitalismo que tiene algo así.

La institución sin fines de lucro recibe donaciones y luego las administra como si fuera una empresa privada corriente, solo que los excedentes deben ponerse al servicio de los fines que persigue la institución. Los excedentes, a diferencia de lo que ocurre en una empresa con fines de lucro, no pueden distribuirse entre los controladores. Ése es el concepto.

No es que el decano no busque dinero y el dueño de un hotel sí. Ambos necesitan dinero. También Madre Teresa de Calcuta necesitaba dinero para poder acompañar y aliviar a los muribundos a quienes dedicó su abnegada vida. Pero la orden que dirigió Madre Teresa de Calcuta no es una empresa comercial. Aunque el dinero que recibe lo invierta en acciones, bonos y propiedades como si fuera una empresa.

Columbia University, donde estudié, es el principal landowner de Manhattan. Cuando se nombra a un nuevo vicerrector económico es entrevistado en The Wall Street Journal. Lo mismo sucede con el de Harvard: su endowment es aproximadamente equivalente a Codelco. Pero la rentabilidad de esas inversiones se destina a la universidad, es decir, a sueldos de profesores, proyectos de investigación, bibliotecas, laboratorios, etc. Lo mismo deben hacer las universidades públicas modernas.

Y, por supuesto, los profesores de cirugía de la Escuela de Medicina prestan servicios como médicos, es decir, operan y obtienen 
por ello una remuneración de mercado, y gracias a ello los estudiantes aprenden a operar con un cirujano que sabe y está al día. Y si un grupo de investigadores descubre una patente, es común que se asocien con la universidad para explotar comercialmente esa patente. Se trata de actividades académicas. Y la editorial de la universidad vende los libros que edita y si hay utilidades son de la universidad. Y así.

Pero hay áreas en las que la venta de servicios no es posible y la universidad las financia. No son los servicios académicos ni la matrícula de los estudiantes los que financian a los historiadores, por ejemplo. Los cursos del college tradicional se centran en disciplinas matrices -historia, matemáticas, ciencia política, música, física, filosofía, arte, economía, biología, literatura-y esa docencia — que requiere profesores talentosos y de gran vocación- está en el corazón de la formación del joven que pasa por la universidad. A eso se dedican los cuantiosos recursos que reciben de personas, de empresas y del Estado.

Los beneficios tributarios y aportes para la investigación se merecen porque la universidad, en su docencia y en su investigación, debe producir externalidades positivas, generar bienes públicos. "Nosotros en los Estados Unidos", escribe Martha Nussbaum, "debiéramos hacer una pausa en este punto y agradecer nuestras tradiciones, que combinan un modelo de artes liberales con el cultivo de una vigorosa filantropía humanística y una estructura de financiamiento basada en las donaciones privadas" (Nussbaum, 2010, p. 132). Según el Bureau of Economic Analysis el año 2009 el sector sin fines de lucro representaba el 5,5\% del GDP.

Así como hay en Estados Unidos universidades estatales (Berkeley, Virginia, NYU, por ejemplo) y privadas sin fines de lucro, también las hay con fines de lucro, que pagan impuestos como cualquier empresa. En otro lugar me he referido a ellas (Fontaine, 2012). No soy partidario de prohibirlas, pero la evidencia de su desempeño, a mi juicio, no les es muy favorable (Riegg Cellini y Goldin, 2012; Kevin Lang y Russell Weinstein, 2012; David J. Deming, Claudia Goldin y Lawrence F. Katz, 2011).

Se han dedicado, en general, a un alumnado de un nivel socioeconómico bajo, algo mayor — la mayoría trabaja - y que busca 
capacitación laboral. Eso es lo positivo: están educando a miles de personas de poca educación y mejorando su capacitación. El 56\% se ha graduado en negocios y servicios de administración. No forman médicos, ni abogados. Son instituciones solo de docencia. Las universidades con fines de lucro "no son el resultado del capitalismo de libre mercado" (Douglass, 2012, p. 6), pues dependen fundamentalmente del subsidio estatal. De hecho entre el $80 \%$ y $90 \%$ de su ingreso proviene de alumnos con becas federales. (En el caso de Phoenix University, la más grande de todas, el $80 \%$ de sus ingresos viene de alumnos subsidiados por el estado Federal.)

La matrícula (año 2009-2010) de las con fines de lucro fue del orden de U\$14.280 contra US\$10.266 de universidades privadas similares, pero sin fines de lucro. Sus graduados terminan con una deuda mayor y se gradúa un tercio de los que se gradúan en instituciones equivalentes sin fines de lucro. La morosidad es de 7,6\% en las universidades privadas y en las con fines de lucro es del orden del $25 \%$.

La gran expansión se produjo durante el gobierno del Presidente Bush alrededor del 2005. La idea fue liberalizar el marco regulatorio, rebajar las exigencias de las agencias de acreditación y aumentar los subsidios estatales. Todo eso se logró. Pero la Spellings Commission recomendó además establecer pruebas estandarizadas para evaluar el aprendizaje de los alumnos al modo en que se hace en el programa "No Child Left Behind", instaurado en esa administración. De hecho, Margaret Spellings fue la figura clave de ese controvertido proyecto que vincula resultados de los alumnos en pruebas estandarizadas anuales con los ingresos de los profesores. Sin embargo, la idea de pruebas estandarizadas para la universidad no prosperó.

Por otra parte - y esto es más grave- proliferan las denuncias por fraude, publicidad engañosa y métodos prohibidos de reclutamiento de alumnos. Algo del 70\% de las investigaciones del Ministerio de Educación de Estados Unidos tiene que ver con irregularidades y delitos de universidades con fines de lucro. Hoy por hoy hay 30 fiscales generales (attorney generals) investigando denuncias de delitos de universidades con fines de lucro.

En un artículo titulado "Para las Universidades con Fines de Lucro la Fiesta Terminó" The Wall Street Journal (22/8/11) informó que: "Los nuevos matriculados han caído —en algunos casos más de un $45 \%$ - en los últimos meses, reflejando dos factores: las compañías 
han refrenado sus agresivas prácticas de reclutamiento ante las críticas de altas tasas de morosidad de los créditos estudiantiles. Y muchos posibles estudiantes están cuestionando el retorno de títulos que cuestan considerablemente más que lo que está disponible en las universidades públicas municipales (community colleges)". El valor de las acciones de estas compañías ha caído.

En Brasil la ley también permite universidades con fines de lucro y se han expandido con fuerza inusitada desde 1996 en adelante. Eso se debe a un marco institucional más libre, financiamiento estatal, y a una gran demanda por educación superior. "El desarrollo del sector en Brasil no fue el resultado de la actividad empresarial espontánea, sino una política deliberada del gobierno" (Mc Cowan, 2004, p. 7). "Las universidades con fines de lucro deben dedicar una fracción de sus utilidades a financiar becas, que se agregan a los préstamos y becas estatales. Han surgido muchísimas universidades de diversos tamaños y características. Entre 1998 y 2001 se fundaron 2 instituciones de educación superior al día" (Constantino y Gois, 2003, citado por Mc Cowan, 2004, p. 18). Algo del 50\% del total de los alumnos estudia en universidades con fines de lucro. La más grande es, posiblemente, la Universidad Paulista, ligada a una cadena de colegios primarios y secundarios del grupo Objetivo. Tienen un total de 485.000 alumnos e ingresos anuales del orden de US\$650 millones de dólares.

El rápido aumento de la cobertura universitaria es —como en Chile - un gran logro y naturalmente ha sido visto con gran esperanza. Sin embargo, la calidad de la enseñanza suscita dudas. "Crece el número de instituciones privadas con ánimo de lucro (...). Muchas de ellas ofrecen simulacros de servicios educativos a bajos costos" (Díaz Sobrinho y Regina F. de Brito, 2008). Mc Cowan sostiene que el sistema es de mala calidad e inequitativo. Si las matrículas no pueden subirse, debido al nivel económico de los estudiantes, entonces "una vez logrado un alto nivel de eficiencia, la utilidad solo puede lograrse gastando menos en infraestructura, personal y así”. Es decir, se rebaja el nivel académico (Mc Cowan, 2004, p. 16). Y el sistema es desigual porque los ingresos de la familia determinan la calidad de la universidad respectiva y, por tanto, el valor de mercado de los respectivos títulos. Pese a las ganancias de cobertura, el sistema "a la larga va a reproducir las desigualdades al confinar a los alumnos de las familias pobres a cursos e instituciones que otorgan diplomas de menos valor en el mercado" (Mc Cowan, 2004, p. 11). 
Por otra parte, esto ha traído como consecuencia un creciente aumento de la regulación. Según un estudio: "Hubo cierta sofisticación en el establecimiento de estos indicadores, ajustándose parámetros a partir de coeficientes de regresión y estableciendo otros criterios como el IDD, que pretende medir el valor agregado de la formación de las carreras, mediante la comparación de notas de los entrantes a determinada carrera, de los egresados, y de la formación cultural promedio de los padres de los estudiantes. La tendencia observada es el aumento de la complejidad de los indicadores que guían a las comisiones del Ministerio de Educación que visitan las instituciones para recomendar el reconocimiento de las carreras y el uso intensivo de estos mismos indicadores para establecer prioridades para el otorgamiento de financiamiento de los estudiantes en las instituciones y carreras" (Centro Interuniversitario de Desarrollo, 2011, p. 35). Otro autor sostiene que "la dinámica del lucro, también promovió un incremento del nivel regulatorio, el cual a su vez incrementa las imperfecciones del mercado (...). Así, por una parte se liberó el funcionamiento de los mercados, y, por otra, se sentaron las bases para un aumento del nivel regulatorio, que crecientemente se ha dado en forma altamente centralizada y politizada. $\mathrm{Y}$ una de cuyas manifestaciones ha sido el establecimiento de mecanismos de aseguramiento de la calidad" (Rama, 2011, p. 7).

Douglass habla del "efecto Brasil": cuando "la educación pública no puede satisfacer la creciente demanda" por acceso a programas de educación superior, las universidades con fines de lucro "se apresuran a llenar ese espacio. Éste es el patrón en muchos países en desarrollo, incluido Brasil" (Douglass, 2012, p. 12). La falta de inversión estatal y, más tarde, el subsidio estatal explicarían el fenómeno. El resultado es "un tipo de política por omisión. El futuro mercado terciario de la educación no será el resultado de una política bien pensada (...) sino un mercado cuasi-libre que promoverá proveedores de baja calidad" incapaces de lograr los niveles educacionales requeridos (Douglass, 2012, p. 2). Dado que el sector universitario con fines de lucro "no se sostiene gracias al libre mercado, sino que gracias a subsidios estatales", la pregunta es qué ocurriría si esos subsidios se destinaran a universidades públicas y a universidades sin fines de lucro (Douglass, 2012, p. 13).

En suma, pareciera que ni Estados Unidos ni Brasil han dado todavía con un marco regulatorio satisfactorio para las universidades con fines de lucro. 
En Brasil la mala calidad de las universidades hace que el Estado intervenga directamente para controlar la calidad de modo centralizado y político. Es decir, lo que comienza como un grito de libertad y confianza en el emprendimiento privado termina en una forma de viejo mercantilismo: empresas privadas de mala calidad que penden del financiamiento y la regulación del Gobierno. Fue justamente contra ese tipo de capitalismo mercantilista que Adam Smith escribió La Riqueza de las Naciones. En el texto del año 2004 ya citado, Juan de Dios Vial Correa lo vio venir: "El problema es francamente grave porque obedece a una falla en los conceptos. Normalmente era la Universidad la que acreditaba conocimientos y competencia intelectual", escribió Vial Correa. "Eso está en el núcleo mismo de su existencia. Nos estamos olvidando de que una universidad verdadera no es una organización cualquiera productiva o burocrática. Ella ha sido desde la Edad Media una institución, o sea una obra social que se genera en la historia y que en este caso reconoce como propia la misión de educar y certificar conocimientos y que se halla centrada en torno a la capacidad y el saber de los más estables de sus miembros. Yo creo que, entre nosotros, el Estado no quiere instituciones; quiere dependencias. Y los 'privados' por su parte tampoco quieren instituciones: quieren asociaciones de conveniencia, que cumplan sus funciones, aun cuando lo hagan al más modesto nivel que les asegure su rentabilidad" (Vial Correa, 2004).

Entonces vean ustedes cómo se van entremezclando los problemas: las instituciones con fines de lucro; el afán del Gobierno por aumentar a toda velocidad la cobertura universitaria, por mejorar el capital humano - lo que sin duda es positivo - y crear, de paso - $\mathrm{y}$ esto, en cambio, es negativo-, al menos la ilusión de movilidad social; el financiamiento estatal vía créditos blandos con aval del Estado; la explosión irresponsable de titulados, $40 \%$ de los cuales en Chile tiene una rentabilidad negativa por su inversión, es decir salen para atrás (Urzúa, 2012); la regulación, por consiguiente, más puntillosa como remedio; las dificultades, imprecisiones y arbitrariedades que inevitablemente tienen las mediciones de la educación universitaria y sus efectos, a menudo perniciosos, en la forma que la educación adopta para adaptarse a ellas; la regulación, por consiguiente, cada vez más pormenorizada e intervencionista que, a su vez, tiene efectos indirectos que distorsionan el mercado — suben los precios, por ejemplo-; a lo que siguen, entonces, nuevas intervenciones gubernamentales cada vez más minuciosas y 
tecnificadas con el fin de orientar y regular la calidad de la enseñanza, el currículum vitae de los profesores, los precios, las carreras, su estructuración, las áreas de investigación, la empleabilidad e ingresos esperados de los graduados. Y, claro, hay que fiscalizar, investigar e imponer sanciones.

Un enfoque fabril de la educación, como lo he llamado (Fontaine, 2012), nos conduce a establecer, entonces, "controles de calidad" de los "productos" de la educación. Nadie, en principio, quiere esto. Pero en nombre de la libertad y el mercado nos deslizamos imperceptiblemente a una forma de despotismo ilustrado.

Por eso creo que ésta es una discusión de fondo: perdonen los que me lo han oído. Lo que está en juego es la autonomía de la universidad, la libertad que le da sentido. La cultura, la ciencia, la formación de la persona, la deliberación democrática se nutren de la libertad que hay en las universidades, en especial de las que educan a las elites. La universidad moderna se inspira, creo, en esa invitación de Kant a liberarse de tutelas: Sapere aude, dice Kant: ¡Atrévete a saber!

La dificultad de regular la universidad docente con fines de lucro hace que uno se pregunte: ¿Por qué? ¿A qué se debe esto? El mercado, con reglas bastante simples y generales, funciona maravillosamente para producir toda una amplia gama de vinos y quesos de diversa calidad y precio, por ejemplo. Jamás la planificación centralizada podría lograr lo que hace el mercado en materia de quesos. La universidad no es un instituto de adiestramiento, como puede serlo un preuniversitario o un instituto de idiomas, cuyo rendimiento es relativamente fácil de medir. En esos casos, el lucro funciona bien. Pero la universidad tiene características muy peculiares (Fontaine, 2012; Barros y Fontaine, 2011).

En la educación universitaria hay cierta irreversibilidad (hay una edad para estudiar y graduarse en la universidad pasada la cual ya es muy costoso educarse de nuevo), hay fuertes asimetrías de información entre la universidad y el alumno; y el lucro hace más tentador sacar ventaja de esas asimetrías y dejarse llevar por un enfoque meramente instrumental (Pusser, 2006). Surgen así las manipulaciones de la publicidad, los engaños (prometer un status social e ingresos ilusorios), los abusos, los fraudes a la ley y a la fe pública. 
El proceso de formación tiene múltiples dimensiones. Lo más importante no puede medirse a través de métodos cuantitativos. Las mediciones son necesarias. Pero hay que tener presente que modifican lo medido. No son neutras como las medidas que uno toma en una casa. La multiplicación de las pruebas de opción múltiple producen un cierto tipo de enseñanza. Tienen la obvia ventaja de la imparcialidad y la velocidad (las corrige una máquina). Pero no ejercitan la capacidad de desarrollar y estructurar un argumento ni oralmente ni por escrito, por ejemplo. Ni la deliberación en el contexto de una interacción social viva. Tampoco ayudan al cultivo de la sensibilidad para comprender a los demás, para imaginar a los que son distintos de mí y han vivido otras vidas, en lo que juega un papel central la literatura, que no tiene mucho sentido examinar a través de pruebas de opción múltiple. Entonces, como eso no se mide, naturalmente se deja de lado.

Las mediciones, premios y castigos no son algo ajeno y sobreañadido a la enseñanza, sino que forman parte de ella. Por ejemplo, hay colegios en Estados Unidos donde se está premiando en dinero a los alumnos que leen la novela indicada por el profesor. (Sospecho que a algunos discípulos de Gary Becker no les debe molestar la idea.) Depende, obviamente, del precio. Pero, digamos, $\$ 3.000$ a cada alumno que en un control de lectura acredite haber leído la primera parte de El Quijote. Supongamos que funciona. ¿Dirían ustedes que esos jóvenes han leído realmente El Quijote? ¿No distorsiona la idea misma de la lectura de una novela en un colegio o una universidad el que se haga así, por plata? ¿No corrompe la educación? ¿Qué pasa si organizamos toda la enseñanza escolar y universitaria con incentivos monetarios en lugar de notas? ¿Y si fuese, quizás, lo más eficiente para "controlar la calidad del producto"?

Para mí el concepto de educación universitaria va por otro lado. La idea es estar junto al joven en ese tiempo de las grandes preguntas, de los descubrimientos intelectuales que abren la mente a una disciplina, del asombro que puede causar una experiencia estética, de las conversaciones sin horario, de las amistades más libres, de los primeros desbordes del amor, de las decisiones quizás más inciertas y, a la vez, más decisivas. Se quiere estar ahí, cerca, para ayudar a la formación que cada persona, a su manera, lleva a cabo en sí misma — en su inteligencia, su sentido moral, su sensibilidad_-, se quiere despertar en el estudiante el interés por ser un ciudadano capaz de participar y deliberar 
en las instituciones propias de la democracia, se quiere explorar el conocimiento asomándose, ojalá, a sus límites, y enseñar profesiones con rigor, con responsabilidad, con alegría ante el trabajo bien hecho.

Ésas son las aspiraciones de la universidad. Es un ideal, ya lo sé. Pero como tal sigue vigente, no como algo estático, inmutable, sino en plena revisión, duda y desenvolvimiento. Es una tarea humilde, pero que tiene su nobleza secreta. Es un ideal que justifica, creo, que, pese a todo, seamos profesores y no queramos dejar de serlo nunca.

\section{REFERENCIAS}

Acemoglu, Daron, y A. Robinson. Why Nations Fail. New York: Crown Business, 2012.

Barros, Enrique y Arturo Fontaine. "Apuntes acerca de la Universidad en Tiempos de Conflicto". Estudios Públicos, No 124, 2011. [Una versión algo más breve de este artículo apareció en El Mercurio el 24/7/2011.]

Centro Interuniversitario de Desarrollo (CINDA). "La Educación Superior en Brasil 2005-2009”. Marzo 2011.

Deming, David J., Claudia Goldin y Lawrence F. Katz. "The For-Profit PostSecundary School Sector: Nimble Critters Or Agile Predators". NBR Working Paper Series 17.710, December, 2011.

Días Sobrinho, José y Marcia Regina F. de Brito. "La Educación Superior en Brasil: Principales Tendencias y Desafíos”. http://www.scielo.br/pdf/ aval/v.13n2/11.pdf, 2008.

Douglass, John Aubrey. "Money, Politics and the Rise of For-Profit Higher Education and the Rise of For-Profit Higher Education in the US: A Story of Supply, Demand and the Brazilian Effect". CSHE, Center for Studies in Higher Education, Berkeley: University of California. Febrero, 2012.

Fontaine, Arturo. "Contra la Visión Fabril de la Educación: ¿Universidades con Fines de Lucro?”. Ciper, 4/8/2012. [Versión revisada en Estudios Públicos, 127 (invierno 2012).]

Lang, Kevin y Russell Weinstein. "Evaluating Student Outcomes at For-Profit Colleges". NBR Working Paper Series 18.201, June, 2012.

Lemaitre, José María. Declaraciones en CIPER, 24/8/11.

Mc Cowan, Tristan. "The Growth of Private Higher Education in Brazil: Implications for Equity and Quality". Journal of Education Policy, 2004.

Nussbaum, Martha C. Not For Profit. Princeton y Oxford: Princeton University Press, 2010.

Pusser, Brian. "Higher Education, Markets, and the Preservation of the Public Good”. En David W. Breneman, Brian Pusser y Sarah E. Turner. Earnings From Learning. New York: State University of New York Press, 2006.

Rama, Claudio. Revista Histedbr On-Line, Campinas, № 44, pp. 3-17, dez 2011. 
Riegg Cellini, Stephanie y Claudia Goldin. "Does Federal Student Aid Rise Tention? New Evidence on For-Profit Colleges". NBER Working Paper $\mathrm{N}^{\circ} 17827$ (2012).

Smith, Adam. The Theory of Moral Sentiments. D. D. Raphael y A. L. Macfie, editores. Indianapolis: Liberty Fund, 1982

The Wall Street Journal. "Para las Universidades con Fines de Lucro la Fiesta Terminó". Agosto 22, 2011.

Urzúa, Sergio, "La Rentabilidad de la Educación Superior en Chile. Revisión de las Bases de 30 años de Políticas Públicas". Estudios Públicos, $\mathrm{N}^{\mathrm{o}} 125$ (verano, 2012).

Vial Correa, Juan de Dios. "Penumbra en la Universidad". La Segunda, 18 de agosto, 2004.

Zunz, Olivier. Philanthropy in America. Princeton y Oxford: Princeton University Press, 2012. 


\title{
UNIVERSIDAD Y LUCRO, O EL DILEMA DE LA COBERTURA*
}

\author{
Ricardo D. Paredes \\ Universidad Católica de Chile
}

\begin{abstract}
Mi interpretación de lo que sucedió en Chile desde 1981 (cuando se promulgó la ley que permitió que se crearan universidades privadas sin fines de lucro) hasta hace unos pocos años, fue que hubo, con el objeto de impulsar el desarrollo de la infraestructura y ampliar la cobertura universitaria, un acuerdo tácito de que los distintos factores, en particular el capital necesario para desarrollar la infraestructura, fuesen remunerados.
\end{abstract}

Ahora, ¿cuál es el origen del debate actual sobre el incumplimiento de la norma que prohíbe el lucro? En el trasfondo de este álgido debate está la evidencia palmaria, precisamente, de que desde 1981 ha habido un aumento explosivo de la matrícula universitaria, del que se infiere la siguiente cadena: universidades que remuneran el desarrollo de su infraestructura tienen mayor capacidad de crecer en matrícula; el aumento en la oferta hace disminuir los estándares de aceptación de alumnos; estándares de admisión más bajos hacen aumentar las tasas de deserción y disminuir los estándares académicos, lo que finalmente se traduce en un deterioro de las competencias profesionales de los graduados y titulados. Conforme a esta cadena, el origen de la "masificación" de la educación universitaria está por consiguiente en la remuneración de la infraestructura. Previsiblemente, entonces, la discusión seguirá centrada en cómo evitar que las universidades usen herramientas legales para transferir rentas y en cómo

Ricardo D. Paredes. Profesor Escuela de Ingeniería, Pontificia Universidad Católica de Chile y CEPPE. Dirección electrónica: rparedes@ing.puc.cl.

Agradezco las conversaciones con Rómulo Chumacero, Rodolfo Lauterbach, Valentina Paredes, Sergio Urzúa y Jaime Vatter, y al proyecto CIE01Conicyt, que financia esta línea de investigación. Evidentemente, solo el autor es responsable de las opiniones aquí expresadas.

* Exposición en el Seminario "Lucro y Universidad", realizado el 28 de agosto de 2012 en el CEP. Véanse en esta misma edición las ponencias de Carlos Peña, Carlos Williamson y Arturo Fontaine. (N. del E.) 
obligarlas a reinvertir. Por cierto, es bueno que haya concordancia entre la letra y el espíritu de la ley.

A mi entender, sin embargo, el problema de fondo que afecta al actual sistema universitario en Chile estriba en la precaria formación escolar de los estudiantes que ingresan a la universidad, en la disminución de los requerimientos de admisión y en falta de fiscalización adecuada de la calidad. Estos problemas no derivan necesariamente del hecho de que existan o no universidades con fines de lucro.

\section{Introducción}

Q surgimiento del debate sobre el incumplimiento respecto de la norma que prohíbe el lucro en el sistema universitario chileno el año 2011 tiene distintas explicaciones. Por cierto que no fue la investigación periodística la que descubrió la posibilidad de lucro solo cuando el ministro de Educación de la época reconoció ante las cámaras que vendió su participación en una universidad y que ello le implicó cierta ganancia.

La idea que sostengo en este ensayo es que el legislador, al momento de promulgar la ley, y luego distintas autoridades, legisladores y fiscalizadores, por más de 20 años no consideraron que debían establecerse resguardos especiales en la relación entre la propiedad de las universidades y sus gobiernos corporativos precisamente porque el objetivo de la ley en su forma original fue aceptar el lucro, y concretamente remunerar las inversiones en infraestructura que razonablemente debían estar integradas en la propiedad de las universidades. Ello, con el objeto de impulsar el desarrollo de la infraestructura y la cobertura educacional. Por lo demás, qué diferencia fundamental haría lucrar en una universidad, en un instituto profesional o en un centro de formación técnica, todos entes de la educación superior chilena, de los cuales solo a las universidades les está vedado. Posiblemente, la explicación que permita entender dicha diferencia entre instituciones obedece al pudor de las elites intelectuales que influyeron en la decisión de la ley y cuyas "almas mater" no concebían un sistema universitario de excelencia fuera del esquema tradicional.

Es que de otra forma no existiría explicación para la desidia (intelectual) de académicos y de fiscalizadores, quienes por más de 20 años lo dejaron pasar. Debió existir conciencia de que, al menos como 
posibilidad, detrás del hecho que universidades no fueran dueñas de su infraestructura, sino que se la arrendaran a sociedades poseídas por los mismos controladores, y de las transacciones de propiedad de universidades podría haber intereses económicos y también lucro ${ }^{1}$.

Así, mi interpretación sobre lo álgido y la oportunidad del debate es que, gatillado por una declaración de un ministro de Educación, hay un trasfondo que responde a una coyuntura en la que el aumento explosivo de la cobertura de la educación superior está fuertemente cuestionado, particularmente desde las universidades tradicionales (lo que también ha sido el caso en los EE.UU.), por la existencia de malas universidades, las que explicarían en parte los altos niveles de deserción universitaria. Desde esa evidencia, la crítica y eventualmente la posibilidad de revertir o frenar la expansión ha sido focalizarse en la letra de la ley respecto de la prohibición de lucro. La vinculación es así casi directa y un buen analista pudo preverla: universidades que remuneran el desarrollo de su infraestructura tienen mayor capacidad de crecer en matrícula; ellas dan cuenta de la masificación, que dado el sistema escolar vigente requiere ir reduciendo los estándares de aceptación de alumnos; ello deriva en mayores dificultades de retención y en el deterioro del status profesional, lo que sumado a la falta de vigilancia y control sobre la calidad permite finalmente cuestionar la masificación y el instrumento más directo que la permitió.

En este ensayo analizo los elementos que, a mi juicio, son fundamentales en la discusión sobre el lucro en las universidades en Chile, centrándome en las consecuencias prácticas de la discusión y de la prohibición.

\section{Lucro desde una perspectiva económica}

El lucro en economía es sinónimo de ganancia, detrás de la cual no hay acepción negativa. Está también en la acepción legal; lucro cesante, por ejemplo, puede decir relación con lo que demanda un taxista cuando su automóvil es chocado por un conductor ebrio y ha debido dejar de trabajar. En este caso, se trata de la ganancia que el taxista legítimamente pudo obtener por su trabajo. Podemos asociar así a lucro,

1 Cada uno de estos elementos no demuestra lucro. Así, por ejemplo, algunas transacciones se han hecho sobre sociedades que incluyen, además de universidades, otras sociedades que sí pueden lucrar; la integración vertical inmobiliarias-universidades tiene también sentido desde la perspectiva de la eficiencia. 
la ganancia, el salario, o el pago por el otorgamiento de un servicio, sin que necesitemos asociarlo con una ganancia ilegítima o excesiva.

La aproximación económica a diversos temas se centra en las consecuencias de las acciones (economía positiva) y no en lo que "deber ser". Así, respecto del hecho de que muchas personas persigan lucrar la economía no tiene instrumental para responder. Por ejemplo, la economía no responde cuánto más justa sería la sociedad si es que las personas fueran más generosas o quisieran donar su tiempo y trabajo, lo que por cierto hace diferente una sociedad. Sí, desde las primeras lecciones de economía, los estudiantes aprenden sobre las consecuencias de que las personas busquen su propio interés, lo que puede resumirse en la siguiente afirmación de Adam Smith, en su libro La Riqueza de las Naciones (1776):

No es de la benevolencia del carnicero, del cervecero o del panadero en la que debiéramos confiar para tener nuestra cena, sino que de la búsqueda de su propio interés.

Desde la perspectiva de política pública, esta frase se traduce en que cuando la caridad no es suficiente para alimentar o educar, entonces el mismo egoísmo, el propio interés, puede ser un motor para hacerlo. Ello, claramente, también es objeto de controversia no solo desde la práctica y de los efectos, sino que está en el centro de la discusión sobre las libertades.

Visiones diferenciadas respecto del rol del lucro en torno a la educación se pueden extrapolar del diálogo sostenido por el general William Westmoreland y Milton Friedman ante la Comisión Presidencial Nixon, cuyo objetivo era analizar el fin del reclutamiento obligatorio en los EE. UU. y sustituirlo por una fuerza militar completamente pagada. El diagnóstico de Friedman era que como no bastaba con el número de voluntarios dispuestos a hacer el servicio militar sin que mediaran pagos, era necesario pagar un salario de modo de generar un contingente suficiente (voluntario), sin requerir el reclutamiento forzoso.

General: No me gustaría comandar un ejército de mercenarios...

Friedman: ¿Es que acaso preferiría comandar una fuerza de esclavos? 
General: No me gusta oír que alguien se refiere a nuestros patriotas reclutas como esclavos.

Friedman: No me gusta oír que alguien se refiera a nuestros patriotas voluntarios como mercenarios. Si ellos son mercenarios, entonces yo, señor, soy un profesor mercenario y Ud., señor, un general mercenario. Somos servidos por médicos mercenarios, usamos abogados mercenarios y obtenemos nuestra comida de carniceros mercenarios ${ }^{2}$.

Así, desde Smith a nuestros tiempos, la idea que la búsqueda de ganancias o lucro hace actuar a las personas y que dichas ganancias están alineadas o pueden alinearse con los objetivos de la sociedad, constituye una piedra angular de la política pública, pues en este sentido las acciones seguidas por el egoísmo compiten, al menos conceptualmente, con la acción directa del Estado. La ganancia, el beneficio, o el lucro, deben entenderse como el pago que induce, para que quienes no son generosos, aporten recursos y esfuerzo.

\section{Lucro normal y la oferta de generosos}

Ciertos niveles de ganancia o lucro podrán superar lo necesario para inducir al aporte de los insumos que poseen las personas y sobre eso, sobre el lucro excesivo, la teoría económica también tiene algo que decir. Las rentas ricardianas, vinculadas literalmente en David Ricardo a la tierra, pero perfectamente extrapolables a cualquier recurso naturalmente escaso, como pudiera ser la capacidad de innovar, de gestionar, o de asumir nuevos proyectos, constituyen exceso de lucro, en el sentido que pueden ser eliminadas sin inducir a los dueños de los factores a entregar menor esfuerzo o aportar menos insumos productivos. Mientras las rentas ricardianas no reducen el aporte de insumos y esfuerzo, las rentas monopólicas sí lo hacen. Sin embargo, la discusión económica sobre el lucro o la ganancia no es sobre excesos, porque sobre estos últimos la teoría económica tiene consensos y las leyes dan o pueden dar cuenta directamente a través de sistemas de impuestos y de la legislación antimonopolios.

2 http://delong.typepad.com/sdj/2012/01/econ-1-uc-berkeley-spring2012-why-we-are-reading-milton-friedman-and-rose-director-friedman-free-tochoose.html. 
La discusión pertinente al lucro en educación es sobre la ganancia normal, aquella de la que la evidencia sugiere que mayoritariamente las personas exigen como retribución por el aporte que entregan. Y si lucro es sinónimo de remuneración necesaria para inducir en algunos el aporte de insumos para generar educación, incluyendo el pago a los sostenedores educacionales, entonces la controversia está erróneamente centrada en el lucro excesivo, el innecesario para que los dueños de los insumos aporten al proceso educacional.

A partir de esta ley, los recursos públicos entregados a las entidades educativas deberán ser destinados precisamente al cumplimiento de la función educativa, porque para eso son los recursos públicos, para ser invertidos en educación y nada más que educación (...). Y vamos a fiscalizar que ello suceda. (Extracto del discurso de la Presidenta Bachelet con ocasión del envío del proyecto de ley que ponía fin a las escuelas con fines de lucro, abril 2007).

Compartiendo el propósito de que los recursos entregados por el Estado deben estar estrictamente orientados a mejorar la educación, dado un esfuerzo estatal, lo que por cierto es objeto de debate, la afirmación previa sugiere ya sea que: i) las instituciones con fines de lucro obtienen ganancias que exceden las necesarias para inducir voluntariamente los aportes de recursos que hacen para entregar una educación de calidad; ii) que es posible cubrir las necesidades de cobertura educativa solo con instituciones sin fines de lucro, o que iii) intrínsecamente, la naturaleza jurídica hace una diferencia en la calidad de la educación que cada una provea o en los costos que la educación le significan al Estado.

Sobre el primer aspecto, exceso de lucro, ya señalamos que hay instituciones que están derechamente orientadas a ese efecto y, más aún, el tema específico del exceso no es parte de la controversia. Sobre los otros dos puntos nos referimos en lo que sigue.

\subsection{Oferta de instituciones sin fines de lucro}

Un error lógico recurrente surge de comparar instituciones con y sin fines de lucro. Como existen algunas personas e instituciones que, con intereses diversos, no requieren remuneración por el aporte que hacen, por ejemplo donando su trabajo o los edificios universitarios, 
entonces pudiéramos deducir que prohibiendo las instituciones con fines de lucro (las que requieren remuneración) obtendremos educación más barata y de mejor calidad. Pero ello será cierto solo si es que hay suficiente oferta de instituciones educativas sin fines de lucro, de modo que ellas satisfagan la demanda por educación. Si la oferta de personas o instituciones generosas no es suficiente para las necesidades de cobertura educativa que definimos como sociedad, necesitaremos de otras formas de proveer educación, y lo que desde la política pública de mediano plazo es evidente, es que la cobertura la hagan las instituciones del Estado, o que éste induzca, mediante subsidios, el incremento de la cobertura por parte de instituciones sin fines de lucro (cambiar las actitudes y generosidad de las personas pudiera ser posible, pero debe tomar más tiempo).

Pero ¿por qué necesitaría una institución sin fines de lucro un subsidio estatal para aumentar su cobertura? El motivo es evidente, si la oferta de generosos no es suficiente, necesitará financiar la nueva infraestructura, los equipos de gestión que el contingente adicional de estudiantes demande, etc. ¿Y si es el Estado el que directamente, en sus propias universidades, provee dichos cupos? Soslayando la discusión sobre la selectividad que las universidades más tradicionales quisieran mantener, tampoco se puede eludir el hecho de que también el Estado requerirá del aporte de insumos, de factores productivos, que no están a libre disposición. Esto es, si es el Estado el que educa directamente, el Estado debe contratar profesores, infraestructura, gestión, y esos recursos tampoco están disponibles para él sin la compensación adecuada, o al menos no en la cantidad suficiente. En este caso, formalmente habrá menos instituciones con fines de lucro, pero no se ahorrarán recursos para la educación.

\section{2 - ¿Son las instituciones sin fines de lucro lo que la sociedad desea?}

El planteamiento anti lucro sugiere desvío de recursos de los propósitos de la educación, lo que descartando el lucro excesivo implicaría una orientación anti educación. Es decir, los recursos obtenidos servirían para el pago justo de los insumos educativos, pero además existirían pagos (o retiros) que no remuneran lo que es necesario para contribuir exactamente a la educación de calidad que la sociedad demanda. 
Es cierto que algunas personas o grupos están dispuestos a entregar sus servicios, como la gestión, e incluso a donar infraestructura sin remuneración. Algunos lo hacen por el amor a la educación, otros porque creen que a través de la educación pueden transmitir valores que les son propios, sin perjuicio de que dichos valores no tienen por qué ser concordantes con los deseados por el Estado. Consecuentemente, es posible que no haya diferencias cuando hablamos de lucro y no lucro. Cuando un grupo quiere transmitir sus valores religiosos o políticopartidistas, cuando quienes toman las decisiones de matrícula y aranceles obtienen de sus propios salarios remuneraciones mayores que las del mercado a través de una institución que formalmente no lucra, o cuando lo que serían excedentes se destinan a inmuebles o construcciones localizadas en lugares de alto valor de la tierra, no hay en principio diferencias desde la perspectiva educacional de si el destino de los excedentes fuera retirado por los gestores.

La diferencia entre instituciones sobre lo que hacen con los excedentes, es decir, la diferencia entre ingresos y gastos después de haber pagado todos los insumos, y que parece haber focalizado la discusión, es fundamentalmente contable, no de fondo. El sentido económico del excedente se refiere a lo que debiera quedar después de haber incurrido en el costo necesario (sentido de costo económico) para proveer educación de calidad. Por ello, desde el punto de vista económico y educativo, no hace diferencia entre una universidad en la que los dueños retiran los excedentes para financiar vacaciones en el Caribe, de otra que paga por factores que no son necesarios para el desarrollo educacional.

Como debe quedar meridianamente claro, ni siquiera la diferencia se puede establecer respecto de instituciones estatales. Tampoco el argumento debiera centrarse en las declaraciones de principio, que poca relación pueden tener con lo que se hace. Si el argumento es que las instituciones con fines de lucro (o las privadas) no tienen valores republicanos o no tienen los valores que el Estado considera que debieran tener, entonces quedamos atrapados en una discusión en la que difícilmente se puede aportar desde la perspectiva económica, sin perjuicio de que tal diferencia de valores sea de alguna manera medible. Y de hecho, también sobre ello hay controversia. Al respecto, y solo como contraste con la idealización de ciertos tipos de escuela o educación, un debate antiguo en el mundo no sugiere una tipología necesariamente más concordante con esos principios y hay claridad en el riesgo de captura de los principios 
idealizados no solo en dictaduras, sino también en contextos de gobiernos democráticos, en camino o en riesgo de transición al totalitarismo ${ }^{3}$.

En esta línea, Chumacero y Paredes (2009) describen la interpretación de Lott (2007) respecto de la génesis de la educación pública en los EE. UU., la que trasluce una visión muy lejos del ideal:

Hacia los años 1820, los legisladores en Nueva York estaban preocupados por el tipo de educación que estaban recibiendo los niños, porque la mayoría de las escuelas (privadas) eran dirigidas por la Iglesia Católica. Con ello, decidieron subsidiar las escuelas protestantes a través de sistemas similares a vouchers. Sin embargo, para atraer más estudiantes a las nuevas escuelas protestantes, ellas comenzaron a enseñar lo que la mayoría de los padres aparentemente deseaban se les enseñara a sus hijos (a leer, escribir y operaciones matemáticas) y a enseñar menos de lo que no querían (entrenamiento protestante). En la medida que los legisladores vieron que su objetivo no se cumplía, progresivamente fueron impulsando que fuera el Estado el que implementara y dirigiera escuelas, lo que ha llevado a algunos observadores a concluir que la educación pública tiene más que ver con adoctrinamiento. Por ejemplo, Lott (1999) muestra que bajo regímenes totalitarios (que son los que tienen los mayores retornos al adoctrinamiento), es más probable hallar mayores niveles de gasto en educación ${ }^{4}$.

\section{Conclusiones}

Lo que hubo en Chile no parece haber sido un error legislativo ni de fiscalización posterior, sino un propósito claro de permitir que los distintos factores, particularmente el capital necesario para desarrollar la infraestructura, fuera remunerado. No proveyéndola el Estado mediante su intervención directa, si no se hubiera permitido la remuneración de los

3 Véase, por ejemplo, en el caso de Chile, en 1972: "Un Sistema Nacional para la Educación Permanente en una Sociedad de Transición al Socialismo" 1973. Argentina: "Cristina Defiende Militancia Política en las Escuelas (La Cámpora)", agosto, 2012, y para Venezuela: http://otogran.com.over-blog. es/article-educacion-venezolana-en-el-contexto-de-la-revolucion-bolivariana-yla-democracia-del-siglo-xxi-66826819.html.

${ }^{4}$ R. Chumacero y R. Paredes: "Should for Profit Schools Be Banned?", 2009; Lott, J., Freedomnomics: Why the Free Market Works and Other Half Baked Theories Don't, 2007. 
distintos factores, habría sido inviable el crecimiento de infraestructura y el aumento de oferta universitaria. Si ello fue o no una buena idea es otra cosa, y posiblemente, a juzgar por el aumento de oferta de cupos, la reducción en los requerimientos de calificación previa de los estudiantes para llenar esos cupos y la falta de fiscalización adecuada respecto de la calidad, no lo fue.

Sin embargo, el origen de ese problema no es la existencia o no de instituciones con fines de lucro, sino fundamentalmente el hecho de que la mayor cobertura se ha inducido sin restricciones a la formación previa, lo que hace que difícilmente, aunque los alumnos logren superar algunas de sus carencias, puedan llegarse a satisfacer las expectativas de quienes ingresan a la educación superior.

Lo que viene es, previsiblemente, que seguirá centrada la discusión en cómo controlar el cumplimiento de la letra de la ley, en cómo evitar que las universidades usen herramientas legales para transferir rentas y en obligarlas a una reinversión. Ello tiene ventajas si se piensa que es bueno disponer de leyes que mantengan consistencia entre espíritu y letra, pero mi interpretación de lo que ha habido en Chile desde 1980, e ininterrumpidamente hasta hace menos de tres años, es un acuerdo tácito en el sentido de que el pago por la inversión, por los aportes de capital, debían ser remunerados, esto es, que en la acepción económica, no jurídica ni contable, el lucro es funcional al aumento de oferta educativa.

Las consecuencias de "cambiar" las reglas del juego, moviéndonos al nuevo consenso sobre aplicar fielmente las reglas que permitan terminar con el lucro en las universidades serán presumiblemente menores en Chile. Es previsible que a las universidades se les exija vender sus inmobiliarias, y en ausencia de usos alternativos reales para ellas se abra un debate enorme sobre los precios de venta, debates sobre lo expropiatorio que pueden llegar a ser, sobre la constitucionalidad, etc. Es menos previsible que en este caso, por la magnitud de los proyectos y por su especificidad, la cobertura se revierta o cambie el destino que hoy tienen - el universitario-, lo que no ocurriría en el caso de una reforma en el mismo sentido de la educación escolar. Sin embargo, aun así, y con propósitos ya no de predecir lo que viene sino muy especialmente de extraer lecciones del caso chileno, cabe hacer el ejercicio conceptual sobre qué educación tendría Chile si es que efectivamente, sin mayor generosidad ni mayor intervención estatal, hubiéramos impedido que existieran las instituciones que hoy están bajo sospecha de lucrar. 
FIGURA $N^{\circ} 1$

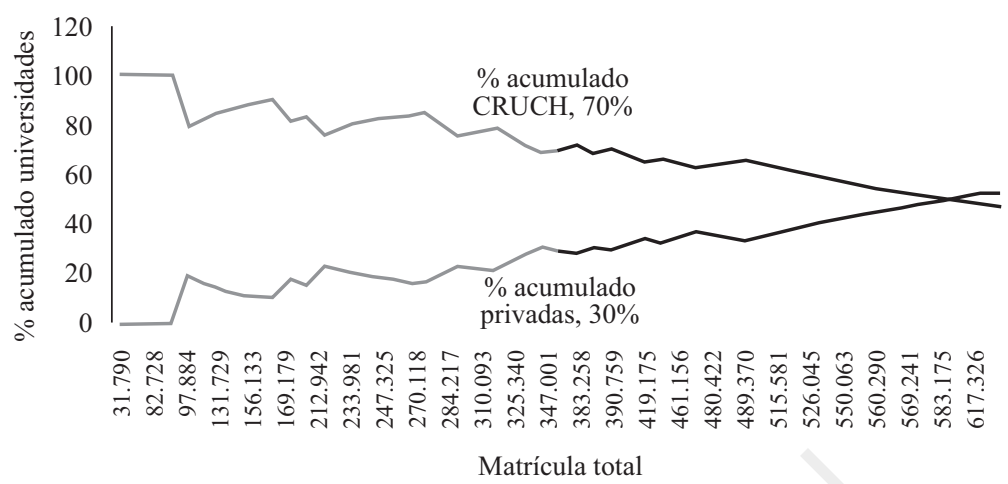

Fuente: R. Paredes, C. Valdivia y A. Barrios (2012): "Calidad de las Universidades en Chile: Rankings, Categorías y Política Pública”, Documento de Trabajo, Departamento de Ingeniería Industrial, PUC.

La Figura $\mathrm{N}^{\circ} 1$, tomada del trabajo de Paredes, Valdivia y Barrios (2012), ilustra el tipo de consecuencias. En el trabajo aludido, y a partir de todas las variables asociadas a calidad universitaria disponibles en Chile y que se usan en los principales rankings de calidad en el mundo, construyen un ranking único y ordenan, de "mejor a peor", las universidades según la matrícula que cubren. Luego, arbitrariamente definimos un grado de selectividad mayor que el que hoy existe, por ejemplo $50 \%$. La figura muestra que si termináramos con las "peores universidades", calificadas según el ranking señalado que sirven el 50\% de los alumnos, en ese caso, el $70 \%$ de los alumnos iría a una universidad del CRUCH y el 30\% iría a universidades privadas creadas con posterioridad a 1980 . Esto es, un sistema más selectivo en calidad estaría más representado por universidades tradicionales que lo que está hoy, pero que si de calidad se trata, no convendría hacer un corte del tipo CRUCH-no CRUCH. Adicionalmente, sabemos que de entre las universidades privadas que prevalecerían por el corte de criterio de calidad, algunas de ellas han sido cuestionadas respecto de su efectiva orientación al lucro.

En síntesis, la calidad del sistema universitario en Chile hoy se basa en universidades tradicionales sin fines de lucro y, también, en otras universidades privadas creadas mayoritariamente después de 1980, de las que no se ha cuestionado su vocación de "no lucro". Hay, sin embargo, algunas que han sido cuestionadas como elusoras de la legislación que prohíbe el lucro, pero que de haberse prescindido de ellas habría habido consecuencias adversas en la calidad del sistema chileno. 


\section{REFERENCIAS BIBLIOGRÁFICAS}

Bachelet, Michelle. Discurso con ocasión del envío del proyecto de ley que ponía fin a las escuelas con fines de lucro, abril 2007.

Comisión Presidencial Nixon. Diálogo entre el general William Westmoreland y Milton Friedman. En http://delong.typepad.com/sdj/2012/01/econ-1-ucberkeley-spring-2012-why-we-are-reading-milton-friedman-and-rosedirector-friedman-free-to-choose.html.

Chumacero, R. y R. Paredes. "Should for Profit Schools Be Banned?". MPRA Paper 15599 (2009). En http://mpra.ub.uni-muenchen.de/15099/.

Lott, John. R. Freedomnomics: Why the Free Market Works and Other HalfBaked Theories Don't. Washington, D.C.: Regnery, 2007.

Paredes, R., C. Valdivia y A. Barrios. "Calidad de las Universidades en Chile: Rankings, Categorías y Política Pública”. Documento de Trabajo, Departamento de Ingeniería Industrial, Pontificia Universidad Católica de Chile, 2012.

Smith, Adam. La Riqueza de las Naciones [1776]. Longseller S.A., 2001.

\section{Documentos:}

Argentina: "Cristina Defiende Militancia Política en las Escuelas (La Cámpora)", agosto, 2012. En http://www.mer.cl/Pages/NewsDetail.aspx?dt=2012-0826\&PaginaId=4\&bodyid $=1$.

Chile: "Un Sistema Nacional para la Educación Permanente en una Sociedad de Transición al Socialismo" [1972]. En La Crisis Educacional. Santiago: Editorial Quimantú, 1973. [http://es.scribd.com/doc/61761598/UnidadPopular-La-crisis-educacional-y-la-Escuela-Nacional-Unificada-1973.]

Venezuela: http://otogran.com.over-blog.es/article-educacion-venezolana-enel-contexto-de-la-revolucion-bolivariana-y-la-democracia-del-sigloxxi-66826819.html. 